\title{
Ovarian Hormone Loss Impairs Excitatory Synaptic Transmission at Hippocampal CA3-CA1 Synapses
}

\author{
Wendy W. Wu, ${ }^{1}$ Damani N. Bryant, ${ }^{2}$ Daniel M. Dorsa, ${ }^{2}$ John P. Adelman, ${ }^{3}$ and James Maylie ${ }^{1}$ \\ ${ }^{1}$ Department of Obstetrics and Gynecology, ${ }^{2}$ Department of Physiology and Pharmacology, and ${ }^{3}$ The Vollum Institute, Oregon Health \& Science University, \\ Portland, Oregon 97239
}

Premature and long-term ovarian hormone loss following ovariectomy (OVX) is associated with cognitive impairment. This condition is prevented by estradiol $\left(\mathrm{E}_{2}\right)$ therapy when initiated shortly following OVX but not after substantial delay. To determine whether these clinical findings are correlated with changes in synaptic functions, we used adult OVX rats to evaluate the consequences of short-term $\left(7-10 \mathrm{~d}, \mathrm{OVX}_{\text {Control }}\right)$ and long-term $\left(\sim 5\right.$ months, $\left.\mathrm{OVX}_{\mathrm{LT}}\right)$ ovarian hormone loss, as well as subsequent in vivo $\mathrm{E}_{2}$ treatment, on excitatory synaptic transmission at the hippocampal CA3-CA1 synapses important for learning and memory. The results show that ovarian hormone loss was associated with a marked decrease in synaptic strength. $\mathrm{E}_{2}$ treatment increased synaptic strength in $\mathrm{OVX}_{\mathrm{Control}}$ but not $\mathrm{OVX}_{\mathrm{LT}}$ rats, demonstrating a change in the efficacy for $\mathrm{E}_{2} 5$ months following $0 \mathrm{VX}$. $\mathrm{E}_{2}$ also had a more rapid effect: within minutes of bath application, $\mathrm{E}_{2}$ acutely increased synaptic strength in all groups except $\mathrm{OVX}_{\mathrm{LT}}$ rats that did not receive in vivo $\mathrm{E}_{2}$ treatment. $\mathrm{E}_{2}$ 's acute effect was mediated postsynaptically, and required $\mathrm{Ca}^{2+}$ influx through the voltage-gated $\mathrm{Ca}^{2+}$ channels. Despite $\mathrm{E}_{2}$ 's acute effect, synaptic strength of $\mathrm{OVX}_{\mathrm{LT}}$ rats remained significantly lower than that of $\mathrm{OVX}_{\text {Control }}$ rats. Thus, changes in CA3-CA1 synaptic transmission associated with ovarian hormone loss cannot be fully reversed with delayed $\mathrm{E}_{2}$ treatment. Given that synaptic strength at $\mathrm{CA3}-\mathrm{CA} 1$ synapses is related to the ability to learn hippocampus-dependent tasks, these findings provide additional insights for understanding cognitive impairment-associated long-term ovarian hormone loss and ineffectiveness for delayed $\mathrm{E}_{2}$ treatment to maintain cognitive functions.

\section{Introduction}

More than 300,000 women in the United States undergo ovariectomy (OVX) for disease treatment and cancer prevention annually (Whiteman et al., 2008). OVX results in a sudden decline in the circulating ovarian hormones including $\mathrm{E}_{2}$, creating "surgical menopause." In humans (Nappi et al., 1999; Farrag et al., 2002; Rocca et al., 2007) and animals (Gibbs, 2000; Markowska and Savonenko, 2002; Daniel et al., 2006), long-term ovarian hormone loss following surgical menopause is associated with cognitive impairment. While $\mathrm{E}_{2}$ therapy initiated shortly following OVX is protective (Sherwin, 1988; Phillips and Sherwin, 1992; Rocca et al., 2007), it has no significant effect when initiated years later (Rocca et al., 2007). Currently the cellular mechanisms underlying these findings are not well understood.

The hippocampus is a target of ovarian hormones including $\mathrm{E}_{2}$, and is necessary for associative learning. In rats, performance

Received May 10, 2013; revised Aug. 14, 2013; accepted Sept. 3, 2013.

Author contributions: W.W.W., J.P.A., and J.M. designed research; W.W.W. and D.N.B. performed research; D.M.D. and J.M. contributed unpublished reagents/analytic tools; W.W.W. and D.N.B. analyzed data; W.W.W., J.P.A., and J.M. wrote the paper.

This work was supported by the Oregon Health and Science University Department of Obstetrics and Gynecology Mission Support Award and Center for Women's Health Circle of Giving Award to W.W.W., and NIH Grants NS020311 to D.M.D, NS038880 and NSO65855 to J.P.A., and MH081860 to J.M.

Correspondence should be addressed to Wendy W. Wu, Oregon Health \& Science University, Department of OB/GYN, Mail Code L-458, 3181 SW Sam Jackson Park Road, Portland, OR 97239. E-mail: wuwendy@ohsu.edu.

D. Bryant's present address: Department of Biology, University of Wisconsin-Eau Claire, Eau Claire, WI 54701.

DOI:10.1523/JNEUROSCI.2001-13.2013

Copyright $\odot 2013$ the authors $\quad 0270-6474 / 13 / 3316158-12 \$ 15.00 / 0$ on hippocampus-dependent tasks is affected by cyclic fluctuations or pharmacological manipulations of $\mathrm{E}_{2}$ levels (Daniel et al., 1997; Fader et al., 1998; Gibbs, 2000; Korol and Kolo, 2002; Luine et al., 2003; Korol et al., 2004; Leuner et al., 2004; Frye et al., 2007). Importantly, long-term ovarian hormone loss following OVX results in hippocampus-dependent learning deficits (Gibbs, 2000; Daniel et al., 2006). Thus, the hippocampus of OVX rats is a reasonable model for evaluating ovarian hormone loss-induced changes relevant for cognition.

Changes in cognitive functions can arise from changes in synaptic transmission. Indeed, pharmacological or genetic manipulations that strengthen CA3-CA1 synaptic transmission enhance hippocampus-dependent learning and memory (Hampson et al., 1998; Tang et al., 1999; Knafo et al., 2012). Conversely, an impaired CA3-CA1 synaptic transmission has been reported for rodent models of normal aging (Barnes et al., 1992) and Alzheimer's disease (Ricoy et al., 2011) that exhibit hippocampusdependent learning and memory deficits (Gallagher and Pelleymounter, 1988; Kadar et al., 1990; Puoliväli et al., 2002). Together, these results suggest that synaptic and cognitive functions are causally linked.

$\mathrm{E}_{2}$ regulates both the structure and function of CA3-CA1 synapses. In OVX rats, in vivo $\mathrm{E}_{2}$ treatment for days increases CA1 spine density (Gould et al., 1990; Woolley and McEwen, 1993), the frequency of CA3 boutons synapsing with multiple CA1 spines (Woolley et al., 1996), and levels of CA1 synaptic proteins (Brake et al., 2001; Liu et al., 2008; Waters et al., 2009)-changes consistent with an increased synaptic strength. $\mathrm{E}_{2}$ also acutely 
increases CA3-CA1 synaptic strength within minutes of bath application (Wong and Moss, 1992; Foy et al., 1999; Bi et al., 2000; Fugger et al., 2001; Sharrow et al., 2002; Smejkalova and Woolley, 2010). This acute effect differs between male and female rats (Teyler et al., 1980; Foy et al., 1984), suggesting that sex hormones regulate acute $\mathrm{E}_{2}$ sensitivity. In this study, we tested the hypothesis that uncompensated ovarian hormone loss following OVX impairs synaptic transmission and affects acute $\mathrm{E}_{2}$ sensitivity at CA3-CA1 synapses, using adult OVX rats that experienced shortterm $\left(7-10 \mathrm{~d}, \mathrm{OVX}_{\text {Control }}\right)$ and long-term $\left(\sim 5\right.$ months, $\left.\mathrm{OVX}_{\mathrm{LT}}\right)$ ovarian hormone loss followed by subsequent in vivo $\mathrm{E}_{2}$ treatment.

\section{Materials and Methods}

Subject. All animal surgeries and experiments were approved by the Institutional Animal Care and Use Committee of the Oregon Health and Science University, and conducted according to the Guide to the Care and Use of Laboratory Animals of the National Institutes of Health. Virgin female F344BNF1 rats ( 2 and 7 months old) were ovariectomized under anesthesia (using a mixture of ketamine, xylazine, and acepromazine) to remove the peripheral source of endogenous $\mathrm{E}_{2}$, according to our published protocol (Wu et al., 2011). Following OVX, rats that were $\sim 7$ months old recovered in their home cages for $7 \mathrm{~d}\left(\mathrm{OVX}_{\text {Control }}\right)$, while rats that were 2 months old recovered in their home cages for 5 months (long-term ovarian hormone-deficient, $\mathrm{OVX}_{\mathrm{LT}}$ ). Then, 72 and $48 \mathrm{~h}$ before being killed, rats in both groups were injected subcutaneously with either $17 \beta$-estradiol ( $\mathrm{E}_{2} ; 10 \mu \mathrm{g}$ in $100 \mu \mathrm{l}$ of sesame oil), or sesame oil $(\mathrm{O})$ alone (see Fig. 1A). This $\mathrm{E}_{2}$ treatment protocol has been shown to increase CA1 spine density (Gould et al., 1990), the frequency of presynaptic CA3 boutons synapsing with multiple CA1 spines (Woolley et al., 1996), and levels of presynaptic and postsynaptic proteins in the CA1 stratum radiatum (Brake et al., 2001; Waters et al., 2009). This $\mathrm{E}_{2}$ treatment protocol produces $\sim 35 \mathrm{pg} / \mathrm{ml}$ ( or $\sim 130 \mathrm{pM}$ ) serum $\mathrm{E}_{2}$ level on the day of being killed (Woolley and McEwen, 1993), a level within the range of a rat during proestrus (Kalra and Kalra, 1974; Smith et al., 1975; Bridges and Byrnes, 2006). Examining the uteri postmortem revealed that $\mathrm{E}_{2}$-injected rats in both $\mathrm{OVX}_{\mathrm{Control}}$ and $\mathrm{OVX}_{\mathrm{LT}}$ groups exhibited uterine hypertrophy, while the O-injected rats exhibited uterine hypotrophy.

Hippocampal slice preparation. Rats were anesthetized with isoflurane and rapidly decapitated. The brain was rapidly removed, and $300 \mu \mathrm{m}$ slices from the left middle third of the hippocampus were cut using a vibrating microtome (VT1000S; Leica Instrument, Leitz) in ice-cold artificial CSF (aCSF) of the following composition (in mM): $119 \mathrm{NaCl}, 26$ $\mathrm{NaHCO}_{3}, 2.5 \mathrm{KCl}, 1 \mathrm{NaH}_{2} \mathrm{PO}_{4}, 1 \mathrm{MgCl}_{2}, 2 \mathrm{CaCl}_{2}$, and 25 dextrose (saturated with a carbogen mixture of $95 \% \mathrm{O}_{2}$ and $5 \% \mathrm{CO}_{2}$ ). Slices were held in carbogen-saturated aCSF at $35^{\circ} \mathrm{C}$ for $30 \mathrm{~min}$, and then at room temperature $\left(22-24^{\circ} \mathrm{C}\right)$ for at least $1 \mathrm{~h}$ before recording.

Electrophysiology. Experiments were performed at room temperature. Hippocampal slices and individual CA1 pyramidal neurons were visualized using a fixed-stage, upright microscope (Axio Examiner; Carl Zeiss) equipped with infrared differential interference contrast optics. The recording chamber was continuously superfused with carbogen-saturated aCSF flowing at a rate of $2-4 \mathrm{ml} / \mathrm{min}$. Recording electrodes were pulled from filamented borosilicate pipettes (BF150-86-10; Sutter Instruments), and had tip resistances of 2-3.5 $\mathrm{M} \Omega$ when filled with aCSF for extracellular field recordings or the following internal solutions for patch-clamp recordings. For voltage-clamp recordings of EPSCs, the internal solution contained the following (in mM): $130 \mathrm{CsMeSO}_{4}, 10$ HEPES, 2 MgATP, 0.4 NaGTP, 10 Tris-phosphocreatine, 3.5 QX-314, with or without $0.2 \mathrm{D} 600$ and 5 BAPTA (see Results), pH adjusted to 7.25 with $\mathrm{CsOH}$, final osmolarity $\sim 310 \mathrm{mOsM}$. For current-clamp recordings of EPSPs, the internal solution contained the following (in $\mathrm{mm}$ ): $140 \mathrm{KMeSO}_{4}, 10 \mathrm{KCl}, 10 \mathrm{HEPES}, 2 \mathrm{MgATP}, 0.4 \mathrm{NaGTP}, 10$ Trisphosphocreatine, with or without 5 BAPTA (see Results), pH adjusted to 7.25 with $\mathrm{KOH}$, final osmolarity $\sim 290 \mathrm{mOsM}$. One or two fine-tipped stimulating electrodes (CE2B55; FHC), connected to an ISO-Flex stimulus isolation unit (A.M.P.I.), were placed in the CA1 stratum radiatum to stimulate the CA3 axon collaterals. In experiments involving two stimulating electrodes, activation of different sets of synapses by each stimulating electrode was verified by the absence of heterosynaptic paired-pulse facilitation (PPF) before the start of the experiment. CA3 region was cut away to eliminate recurrent excitation within the CA3 subfield. For extracellular field recordings, the stimulating and recording electrodes were placed in the middle-to-distal portion of the CA1 stratum radiatum, as the range of stimulus strengths that could be applied there without evoking a population spike was much wider than that could be applied more proximally. Stimulus duration was $0.1 \mathrm{~ms}$, allowing for clear separation of fiber volley (FV) from the preceding stimulus artifact (Fig. 1B, insets). For whole-cell patch-clamp recordings, the stimulating electrodes were positioned in the proximal CA1 stratum radiatum $\sim 150 \mu \mathrm{m}$ away from the stratum pyramidale. Glutamate release was evoked with one or two synaptic stimuli, each $1 \mathrm{~ms}$ in duration and $50 \mathrm{~ms}$ in interstimulus interval in the case of the paired-pulse protocol, delivered once every $20 \mathrm{~s}$.

Recordings were obtained using a Multiclamp 700B amplifier (Molecular Devices). Signals were filtered at $4 \mathrm{kHz}$, digitized using a Digidata $1440 \mathrm{~A}$ interface (Molecular Devices) at $10 \mathrm{kHz}$, and transferred to a computer using pClamp10 software (Molecular Devices). For whole-cell patch-clamp recordings, membrane potential values were not corrected for liquid junction potential. For voltage-clamp recordings, membrane potential was held at -80 or $-35 \mathrm{mV}$ for AMPA or NMDA receptormediated EPSCs, respectively. Series resistance $(8.2 \pm 0.2 \mathrm{M} \Omega, n=93)$ was not compensated and did not change by $>10 \%$ throughout the course of the experiment. For current-clamp recordings of EPSPs, membrane potentials were maintained at $-65 \mathrm{mV}$ with bias current injection to normalize the basal availability of voltage-gated ion channels known to affect EPSP amplitude (Stuart and Sakmann, 1995; Lipowsky et al., 1996; Gillessen and Alzheimer, 1997; Johnston et al., 2000; Ngo-Anh et al., 2005; George et al., 2009). Series resistance ( $10.1 \pm 0.2 \mathrm{M} \Omega, n=95)$ was electronically compensated in bridge mode.

All experiments were performed in the presence of SR95531 $(5 \mu \mathrm{M})$ and CGP55845 $(2.5 \mu \mathrm{M})$ to block inhibitory synaptic transmission. In some experiments (see text), D-AP5 (50 $\mu \mathrm{M})$ or CNQX $(25 \mu \mathrm{M})$ was also present throughout the recordings to block NMDA or AMPA receptors, respectively. Following a stable period of baseline recording in control aCSF, $\mathrm{E}_{2}(100 \mathrm{pm})$ was bath applied to assess its acute effect on excitatory synaptic transmission.

Western blotting. The right hippocampi were dissected out, frozen in liquid nitrogen, and then stored at $-80^{\circ} \mathrm{C}$ until processing. Individual hippocampi were homogenized on ice in extraction buffer containing the following (in mM): 1 HEPES, 5 EDTA, 5 EGTA, $9 \mathrm{NaCl}, 105 \mathrm{Na}$ pyrophosphate, $1 \mathrm{NaF}, 0.1 \mathrm{Na}$-orthovanadate, and $1 \beta$-glycerophosphate, $\mathrm{pH}$ 7.5. Protein $(20 \mu \mathrm{g})$ from whole-cell lysates was separated on $4-012 \%$ Bis-Tris gels (Life Technologies). After transfer to PVDF membranes, samples were sequentially probed using antibodies against estrogen receptor $\alpha(\mathrm{ER} \alpha$; 6F11, Santa Cruz Biotechnology), estrogen receptor $\beta$ (ER $\beta$; PA1310B, Thermo Scientific), and GAPDH (Thermo Scientific). GAPDH signal was used to normalize protein loading. Chemiluminescent bands were visualized and quantified on a UVP EpiChemi Darkroom. Densitometric data were represented as the ratio of ER $\alpha /$ GAPDH or ER $\beta / G A P D H$.

Drugs. SR95531, CGP55845, QX-314, CNQX, and D-AP5 were purchased from Tocris Cookson and others from Sigma. CGP55845, $\mathrm{E}_{2}$ (for bath application), and nimodipine were dissolved as stock solutions in dimethylsulfoxide (DMSO). The final concentration of DMSO in aCSF was $<0.1 \%$.

Data and statistical analyses. Current and voltage traces were analyzed using custom macros written in Igor Pro (WaveMetrics. Statistical analyses were performed using StatView (SAS Institute). Data are presented as mean \pm SEM, and compared statistically using paired $t$ test, two-factorial ANOVA [variables: post-OVX interval without ovarian hormones $\left(\mathrm{OVX}_{\mathrm{Control}}\right.$ vs $\left.\mathrm{OVX}_{\mathrm{LT}}\right)$ and in vivo $\mathrm{E}_{2}$ treatment status $\left(\mathrm{E}_{2}\right.$ vs O injections)], repeated-measures ANOVA, Fisher's PLSD post hoc test, and Fisher's $r$ to $z$ transformation as appropriate. $p \leq 0.05$ was accepted as statistically significant. ${ }^{\star} p \leq 0.05,{ }^{\star *} p \leq 0.01$, and ${ }^{\star * *} p \leq 0.001$, respectively. 


\section{Results}

Ovarian hormone loss is associated with a progressive reduction in synaptic strength

$\mathrm{OVX}_{\text {Control }}$ and $\mathrm{OVX}_{\mathrm{LT}}$ rats received subcutaneous injections of either $\mathrm{E}_{2}$ or sesame oil vehicle $(\mathrm{O})$ before electrophysiological recordings, resulting in four experimental groups of rats: $\mathrm{OVX}_{\text {Control }}+$ $\mathrm{E}_{2}, \mathrm{OVX}_{\text {Control }}+\mathrm{O}, \mathrm{OVX}_{\mathrm{LT}}+\mathrm{E}_{2}$, and $\mathrm{OVX}_{\mathrm{LT}}+\mathrm{O}$ (Fig. 1A). To quantify the strength of CA3-CA1 synaptic transmission for comparison across these groups, we made extracellular recordings of presynaptic FVs and field EPSPs (fEPSPs) evoked by synaptic stimuli of varying intensities. Increasing the stimulus intensity resulted in FVs and fEPSPs of increasing amplitudes (Fig. 1B, top). Plotting the initial slopes of fEPSPs (primarily reflecting activation of the postsynaptic AMPA receptors) against the FV amplitudes (predominantly reflecting the number of CA3 axons that fired an action potential, or $\mathrm{AP})$ yielded an input-output (I/O) relation for CA3-CA1 synapses (Fig. $1 B$, bottom). The I/O relations constructed from individual experiments were well fit with linear functions. The slopes of these linear fits (or "I/O slopes") reflect the composite cellular transfer function between presynaptic AP-evoked glutamate release and postsynaptic membrane response. Therefore, I/O slopes may be viewed as a measure of synaptic strength.

There was a significant effect of the post-OVX interval without ovarian hormones on $\mathrm{I} / \mathrm{O}$ slopes $\left(\mathrm{OVX}_{\text {Control }}\right.$ vs $\mathrm{OVX}_{\mathrm{LT}}$; $\left.F_{(1,88)}=22.4, p<0.0001\right)$. On average, the I/O slope measured from $\mathrm{OVX}_{\mathrm{LT}}$ rats was significantly smaller than, and only $46 \%$ of that measured from, $\mathrm{OVX}_{\text {Control }}$ rats OVX $_{\text {Control }}: 1.12 \pm 0.11$ $\mathrm{ms}^{-1}, n=46 . \mathrm{OVX}_{\mathrm{LT}}$ : $\left.0.52 \pm 0.05 \mathrm{~ms}^{-1}, n=46 . p<0.0001\right)$. Assuming invariance in AMPA receptor kinetics (verified with whole-cell voltage-clamp recordings of isolated AMPA receptormediated EPSCs; see subsequent results and Table 1), the smaller I/O slope measured from $\mathrm{OVX}_{\mathrm{LT}}$ rats indicates that firing of a given number of CA3 axons activated only half as many AMPA receptors in $\mathrm{OVX}_{\mathrm{LT}}$ relative to $\mathrm{OVX}_{\mathrm{Control}}$ rats. There was also an interactive effect between the post-OVX interval without ovarian hormones and subsequent in vivo $\mathrm{E}_{2}$ treatment on $\mathrm{I} / \mathrm{O}$ slopes $\left(F_{(1,88)}=4.99\right.$, $p<0.05)$. On average, the I/O slope measured from $\mathrm{OVX}_{\text {Control }}+\mathrm{E}_{2}$ rats was $57 \%$ larger than that measured from $\mathrm{OVX}_{\mathrm{Control}}+\mathrm{O}$ rats $\left(\mathrm{OVX}_{\text {Contral }}+\mathrm{E}_{2}, 1.30 \pm 0.15 \mathrm{~ms}^{-1}, n=28 . \mathrm{OVX}_{\text {Control }}+\mathrm{O}, 0.83 \pm\right.$ $0.11 \mathrm{~ms}^{\text {(n) }}, n=18 . p<0.05$; Fig. $1 B$, left; $\left.C\right)$. This demonstrates that in vivo $\mathrm{E}_{2}$ treatment in $\mathrm{OVX}_{\text {Control }}$ rats significantly increased synaptic strength. In contrast, no difference was observed in the I/O slopes for $\mathrm{OVX}_{\mathrm{LT}}$ rats that received either $\mathrm{E}_{2}$ or $\mathrm{O}$ injections $\left(\mathrm{OVX}_{\mathrm{LT}}\right.$ $+\mathrm{E}_{2}, 0.50 \pm 0.07 \mathrm{~ms}^{-1}, n=22 ; \mathrm{OVX}_{\mathrm{LT}}+\mathrm{O}, 0.54 \pm 0.06 \mathrm{~ms}^{-1}, n=$ 24; Fig. $1 B$, right; $C$ ). Post hoc analysis shows that I/O slopes measured from both $\mathrm{OVX}_{\mathrm{LT}}+\mathrm{E}_{2}$ and $\mathrm{OVX}_{\mathrm{LT}}+\mathrm{O}$ rats were significantly smaller than the I/O slope measured from either $\mathrm{OVX}_{\mathrm{Control}}+\mathrm{E}_{2}$ or $\mathrm{OVX}_{\text {Control }}+\mathrm{O}$ rats (Fig. 1C). Quantitatively, the I/O slope from $\mathrm{OVX}_{\mathrm{LT}}+\mathrm{E}_{2}$ rats was 38 and $60 \%$ of those from OVX
Table 1. EPSC characteristics and Pr at CA3-CA1 synapses

\begin{tabular}{|c|c|c|c|}
\hline $\begin{array}{l}\mathrm{EPSC}_{1} \\
\text { rise time } \\
\text { (ms) }\end{array}$ & $\begin{array}{l}\mathrm{EPSC}_{1} \\
\text { half-width } \\
\text { (ms) }\end{array}$ & $\begin{array}{l}\mathrm{EPSC}_{1} \\
\text { decay } \tau(\mathrm{ms}) \quad \mathrm{PPR}\end{array}$ & $\begin{array}{l}\mathrm{CV}^{-2} \text { of } \\
\mathrm{EPSC}_{1} \\
\text { amplitude }\end{array}$ \\
\hline
\end{tabular}

$\mathrm{OVX}_{\text {control }}+\mathrm{E}_{2}(23) \quad 1.99 \pm 0.1312 .63 \pm 0.61 \quad 10.26 \pm 0.542 .16 \pm 0.18 \quad 15.0 \pm 2.4$ $\mathrm{OVX}_{\text {Control }}+0$ (13) $1.87 \pm 0.12 \quad 11.22 \pm 0.28 \quad 8.75 \pm 0.24 \quad 2.16 \pm 0.2815 .2 \pm 3.4$ $0 \mathrm{VX}_{\mathrm{LT}}+\mathrm{E}_{2}(22) \quad 2.06 \pm 0.1912 .24 \pm 0.51 \quad 9.12 \pm 0.27 \quad 1.80 \pm 0.11 \quad 16.0 \pm 2.1$ $\mathrm{OVX}_{\mathrm{LT}}+0(16) \quad 1.78 \pm 0.14 \quad 12.74 \pm 1.33 \quad 9.89 \pm 1.17 \quad 1.95 \pm 0.15 \quad 16.6 \pm 3.5$

Note that one or two independent CA3-CA1 pathways in the proximal stratum radiatum were tested per each hippocampal slice (see Materials and Methods). The numbers in the parentheses thus indicate the numbers of independent pathways tested for individual groups, from the following number of rats and hippocampal slices: $\mathrm{OVX}_{\text {control }}+\mathrm{E}_{2}$, six rats, 12 slices; $0 \mathrm{VX} \mathrm{C}_{\text {control }}+0$, four rats, 8 slices; $0 \mathrm{VX} \mathrm{LT}_{\mathrm{LT}}+\mathrm{E}_{2}$, four rats, 12 slices; and $0 \mathrm{VX}_{\mathrm{LT}}+0$, three rats, 10 slices.

trol $+\mathrm{E}_{2}$ and $\mathrm{OVX}_{\text {Control }}+\mathrm{O}$ rats, respectively, and the I/O slope from $\mathrm{OVX}_{\mathrm{LT}}+\mathrm{O}$ rats was 42 and $65 \%$ of those from OVX $\mathrm{OVX}_{\text {Control }}+\mathrm{O}$ rats, respectively. Together, these results show that ovarian hormone loss following OVX is associated with a significant reduction in the strength of CA3-CA1 synaptic transmission. This change occurs rapidly; it is evident after only $10 \mathrm{~d}$ of ovarian hormone loss, and is progressive. Moreover, $\mathrm{E}_{2}$ treatment initiated $7 \mathrm{~d}$ but not 5 months following OVX is associated with an increased synaptic strength, revealing a dependence of the therapeutic efficacy of $\mathrm{E}_{2}$ treatment on the duration of ovarian hormone loss.

\section{Long-term ovarian hormone loss is associated with a reduction in presynaptic excitability}

The extracellular recording data permitted an estimate of presynaptic excitability for comparison across groups. Presynaptic excitability is operationally defined here as the increase in FV as a 


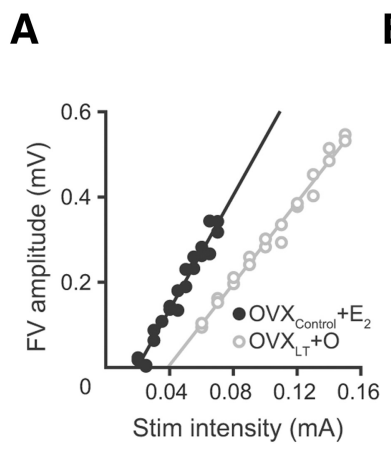

B
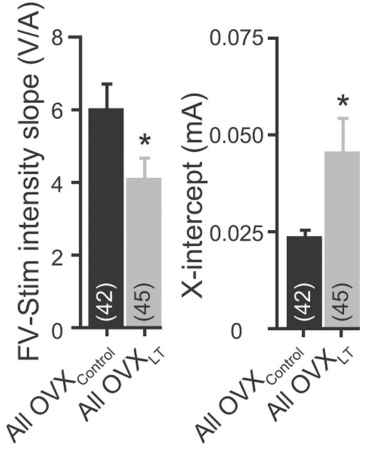

Figure 2. Long-term ovarian hormone loss is associated with a reduction in presynaptic excitability. $A$, Representative FV amplitude versus stimulus intensity relations from an $\mathrm{OVX}_{\text {control }}+\mathrm{E}_{2}$ rat and an $0 \mathrm{VX}_{\mathrm{LT}}+0$ rat. Data were fit with linear functions without constraints. The slopes and the extrapolated $X$-intercepts are as follows: $0 \mathrm{VX}_{\text {control }}+\mathrm{E}_{2}, 6.71 \pm 0.02 \mathrm{~V} / \mathrm{A}, 0.02 \mathrm{~mA} ; 0 \mathrm{VX} \mathrm{LT}_{\mathrm{LT}}+0,4.78 \pm$ $0.04 \mathrm{~V} / \mathrm{A}, 0.04 \mathrm{~mA}$. B, Summary bar graphs for FV-stimulus intensity slope (left) and $X$-intercept (right). ${ }^{*} p<0.05$ compared with $0 \mathrm{VX}_{\text {control }}$ group.

function to increase in the stimulus intensity. This was quantified by plotting the FV amplitude against the stimulus intensity for individual experiments (Fig. $2 A)$. In most cases $\left(\mathrm{OVX}_{\text {Control }}, n=\right.$ 42/46; $\mathrm{OVX}_{\mathrm{LT}}, n=45 / 46$ ), the $\mathrm{FV}$-stimulus intensity relations were well fit with linear functions, with the slope reflecting the collective excitability of the CA3 axon collaterals. There was a significant effect of the post-OVX interval without ovarian hormones, but not in vivo $\mathrm{E}_{2}$ treatment, on the slopes of the FVstimulus intensity relations $\left(F_{(1,83)}=5.23, p<0.05\right)$. On average, the slope measured from $\mathrm{OVX}_{\mathrm{LT}}$ rats was significantly smaller than, and only $68 \%$ of that measured from $\mathrm{OVX}_{\text {Control }}$ rats $\left(O V X_{\text {Control }}: 6.01 \pm 0.69 \mathrm{~V} / \mathrm{A}, n=42 . \mathrm{OVX}_{L T}: 4.06 \pm 0.58 \mathrm{~V} / \mathrm{A}\right.$, $n=45$. $p<0.05$; Fig. $2 B$, left). This suggests that synaptic stimulus of a given intensity activates only $2 / 3$ the number of CA3 axon collaterals in $\mathrm{OVX}_{\mathrm{LT}}$ rats as in OVX also a significant effect of the post-OVX interval without ovarian hormones, but not in vivo $\mathrm{E}_{2}$ treatment, on the $X$-intercepts extrapolated from the linear fit of the FV-stimulus intensity relations $\left(F_{(1,77)}=5.0, p<0.05\right)$. On average, the $X$-intercept, or the threshold for $\mathrm{FV}$ detection, was nearly twice as large for $\mathrm{OVX}_{\mathrm{LT}}$ rats as for $\mathrm{OVX}_{\text {Control }}$ rats $\left(\mathrm{OVX}_{\text {Control }}: 0.023 \pm 0.002 \mathrm{~mA}\right.$; $\mathrm{OVX}_{\mathrm{LT}}: 0.045 \pm 0.009 \mathrm{~mA} . p<0.05$; Fig. $2 B$, right). Thus, longterm ovarian hormone loss is associated with a reduction in presynaptic excitability. This change could reflect a decrease in either the density and/or excitability of individual CA3 axon collaterals. We did not further address the cellular mechanisms underlying this reduction in presynaptic excitability, and rather focused our effort on determining the consequences of ovarian hormone loss and subsequent in vivo $\mathrm{E}_{2}$ treatment on CA3-CA1 excitatory synaptic transmission.

\section{Hippocampal $E_{2}$ receptor levels are not altered by ovarian hormone loss or in vivo $\mathrm{E}_{2}$ treatment}

$\mathrm{E}_{2}$ regulates gene transcription by activating estrogen receptors (Marino et al., 2006). Both isoforms of the classical estrogen receptors, $\operatorname{ER} \alpha$ (Milner et al., 2001) and $\operatorname{ER} \beta$ (Milner et al., 2005), are expressed in the hippocampus. To evaluate whether the I/O slopes of the four experimental groups of rats correlate with the relative protein levels of $\mathrm{ER} \alpha$ and $\mathrm{ER} \beta$ in the hippocampus, Western blot analysis was performed on individual hippocampal protein preparations. There was no significant effect of the postOVX interval without ovarian hormones or in vivo $\mathrm{E}_{2}$ treatment on the levels of $\operatorname{ER} \alpha$ or $\operatorname{ER} \beta$ (Fig. 3). While changes in the subcellular localization of $\operatorname{ER} \alpha$ and $\operatorname{ER} \beta$ as a function of ovarian hormone loss or in vivo $\mathrm{E}_{2}$ treatment cannot be ruled out, these results nonetheless show that changes in the hippocampal levels of estrogen receptors do not contribute to differences in synaptic strength across groups.

\section{Acute effects of $\mathrm{E}_{2}$ on synaptic transmission}

In vitro, $\mathrm{E}_{2}$ has been shown to strengthen $\mathrm{CA} 3-\mathrm{CA} 1$ synaptic transmission within minutes of bath application (Wong and Moss, 1992; Foy et al., 1999; Bi et al., 2000; Fugger et al., 2001; Sharrow et al., 2002; Smejkalova and Woolley, 2010). To determine whether this acute $\mathrm{E}_{2}$ sensitivity is affected by ovarian hormone loss and subsequent in vivo $\mathrm{E}_{2}$ treatment, $\mathrm{E}_{2}$ (100 pM), a physiological concentration that can measured in the serum of an intact female rat (Kalra and Kalra, 1974; Smith et al., 1975), was bath applied following baseline recordings for a subset of extracellular field recording experiments.

Bath application of $\mathrm{E}_{2}$ acutely increased the strength of CA3-CA1 synaptic transmission for both $\mathrm{OVX}_{\text {Control }}+\mathrm{E}_{2}$ and $\mathrm{OVX}_{\text {Control }}+\mathrm{O}$ rats. The fEPSP evoked by a given FV amplitude increased significantly following $\mathrm{E}_{2}$ application, resulting in an increase in the $\mathrm{I} / \mathrm{O}$ slopes $\left(\mathrm{OVX}_{\mathrm{Control}}+\mathrm{E}_{2}: a C S F, 1.30 \pm 0.15\right.$ $\mathrm{ms}^{-1}$; + bath $E_{2}, 1.87 \pm 0.28 \mathrm{~ms}^{-1} ; 39 \pm 8 \%$ increase relative to baseline; $n=28 . p=0.001 ; \mathrm{OVX}_{\text {Control }}+\mathrm{O}: a C S F, 0.83 \pm 0.11$ $\mathrm{ms}^{-1}$; +bath $E_{2}, 1.20 \pm 0.17 \mathrm{~ms}^{-1} ; 46 \pm 9 \%$ increase; $n=18$. $p<0.001$; Fig. $4 A, C)$. Bath application of $\mathrm{E}_{2}$ also increased the I/O slope of OVX $\mathrm{LT}+\mathrm{E}_{2}$ rats $\left(a C S F, 0.46 \pm 0.08 \mathrm{~ms}^{-1} ;\right.$ + bath $E_{2}$, $0.60 \pm 0.09 \mathrm{~ms}^{-1} ; 37 \pm 11 \%$ increase; $n=18 . p<0.01$; Fig. $\left.4 C\right)$, but had no effect in $\mathrm{OVX}_{\mathrm{LT}}+\mathrm{O}$ rats $\left(a C S F, 0.62 \pm 0.07 \mathrm{~ms}^{-1}\right.$; + bath $E_{2}, 0.62 \pm 0.08 \mathrm{~ms}^{-1} ; n=18$; Fig. $\left.4 B, C\right)$. These results demonstrate that the acute $\mathrm{E}_{2}$ sensitivity at CA3-CA1 synapses is retained after $10 \mathrm{~d}$ of ovarian hormone loss, but is abolished by 5 months of ovarian hormone loss. Surprisingly, in vivo $\mathrm{E}_{2}$ treatment initiated after 5 months of delay following OVX restored the acute $\mathrm{E}_{2}$ sensitivity (Fig. $4 \mathrm{C}$ ), even though it had no effect on the basal synaptic strength (Fig. $1 C$ ).

The percentage increase in the I/O slopes following bath application of $\mathrm{E}_{2}$ was comparable among $\mathrm{OVX}_{\text {Control }}+\mathrm{E}_{2}, \mathrm{OVX}_{\text {Control }}+\mathrm{O}$, and $\mathrm{OVX}_{\mathrm{LT}}+\mathrm{E}_{2}$ rats (Fig. $4 C$ ). However, even with $\mathrm{E}_{2}$ added to the bath, the I/O slope of $\mathrm{OVX}_{\mathrm{LT}}+\mathrm{E}_{2}$ rats was still significantly smaller

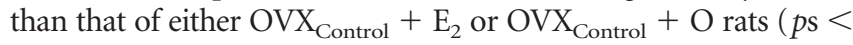
0.001 and 0.01 , respectively). Thus, CA3-CA1 synaptic transmission in $\mathrm{OVX}_{\mathrm{LT}}$ rats cannot be fully restored to the level seen in $\mathrm{OVX}_{\mathrm{Control}}$ rats with a combination of in vivo $\mathrm{E}_{2}$ treatment and acute $\mathrm{E}_{2}$ application.

\section{Long-term ovarian hormone loss and acute $\mathrm{E}_{2}$ application do not affect glutamate release}

The changes in I/O slope associated with ovarian hormone loss and subsequent in vivo $\mathrm{E}_{2}$ treatment (Fig. $1 C$ ) and the increase in $\mathrm{I} / \mathrm{O}$ slope following bath application of $\mathrm{E}_{2}$ (Fig. 4C) may reflect presynaptic and/or postsynaptic mechanisms. To determine whether changes in the release probability $(\mathrm{Pr})$ of glutamate by CA3 axon terminals play a role, whole-cell voltage-clamp recordings were made from CA1 pyramidal neurons to measure evoked AMPA receptor-mediated EPSCs. Neurons were voltage clamped at $-80 \mathrm{mV}$, and recordings were made in the presence of the NMDA receptor blocker D-AP5 $(50 \mu \mathrm{M})$, using a Cs ${ }^{+}$-based internal solution containing QX-314, D600, and BAPTA that minimizes activation of the postsynaptic voltage-dependent $\mathrm{Na}_{\mathrm{V}}, \mathrm{Ca}_{\mathrm{V}}$, and $\mathrm{Ca}^{2+}$ activated ionic conductances, respectively. 
Glutamate release was evoked with a paired-pulse protocol, with the stimulus intensity set at a level so that the first evoked EPSC $\left(\right.$ EPSC $_{1}$ ) was of similar amplitude across groups $\left(\mathrm{OVX}_{\mathrm{Control}}+\right.$ $\mathrm{E}_{2}:-121.0 \pm 16.6 \mathrm{pA}, n=23$ OVX $_{\text {Control }}$ $+\mathrm{O}:-120.9 \pm 15.4 \mathrm{pA}, n=13 ; \mathrm{OVX}_{\mathrm{LT}}+$ $\mathrm{E}_{2}:-139.1 \pm 10.7 \mathrm{pA}, n=22 ; \mathrm{OVX}_{\mathrm{LT}}+$ $\mathrm{O}:-129.1 \pm 14.2 \mathrm{pA}, n=16)$. There was a significant effect of the post-OVX interval without ovarian hormones, but not in vivo $\mathrm{E}_{2}$ treatment, on the stimulus intensity used $\left(F_{(1,67)}=10.594, p<0.001\right)$. On average, the stimulus intensity required for $\mathrm{OVX}_{\mathrm{LT}}$ rats was twice the amount required for $\mathrm{OVX}_{\mathrm{Control}}$ rats $\left(\mathrm{OVX}_{\mathrm{Control}}\right.$ : $11 \pm 1 \mu \mathrm{A}, n=36$; $\mathrm{OVX}_{\mathrm{LT}}: 21 \pm 3 \mu \mathrm{A}$, $n=38 . p<0.001)$. This difference is consistent with the extracellular recording results that showed a larger stimulus threshold for activating a detectable FV and a smaller slope for the FV-stimulus intensity relation in $\mathrm{OVX}_{\mathrm{LT}}$ relative to OVX $_{\text {Control }}$ rats (Fig. 2).

Representative EPSCs recorded from each experimental group of rats are shown in Figure 5A. No difference was detected in EPSC kinetics, including $20-80 \%$ rise time, half-width, and decay time constant (Table 1). Thus, AMPA receptor gating properties do not appear to be affected by ovarian hormone loss or in vivo $\mathrm{E}_{2}$ treatment. Pr was estimated using two parameters that are sensitive to changes in the presynaptic function (Malinow and Tsien, 1990; Manabe et al., 1993; Dobrunz and Stevens, 1997). The first is the degree of PPF (or $\mathrm{EPSC}_{2} / \mathrm{EPSC}_{1}$ ), which at the hippocampal synapses reflects a form of short-term presynaptic plasticity that is inversely related to the initial $\operatorname{Pr}$ (Dobrunz and Stevens, 1997; Murthy et al., 1997; Turner et al., 1997). The second parameter is the square of the inverse of the coefficient of variation $\left(\mathrm{CV}^{-2}\right)$ of $\mathrm{EPSC}_{1}$ amplitude measured across multiple consecutive trials. Assuming invariance in the postsynaptic membrane response to glutamate from trial to trial, $\mathrm{CV}^{-2}$ may serve as an index of glutamate release reliability that is related to the Pr evoked by each presynaptic AP (Korn et al., 1981; Malinow and Tsien, 1990). No difference was found in PPF or CV ${ }^{-2}$ of EPSCs across groups, suggesting that Pr at CA3-CA1 synapses is not significantly affected by ovarian hormone loss or subsequent in vivo $\mathrm{E}_{2}$ treatment (Table 1).

To determine whether $E_{2}$ acutely increases $\operatorname{Pr}, E_{2}$ was bath applied following a stable period of baseline recordings for a subset of voltage-clamp experiments. Figure $5 \mathrm{~A}$ shows the summary time course plots of normalized EPSC ${ }_{1}$ amplitudes measured first in control aCSF followed by $\mathrm{E}_{2}$ application. Bath application of $\mathrm{E}_{2}$ did not affect the amplitude and $\mathrm{CV}^{-2}$ of $\mathrm{EPSC}_{1}$ or PPF measured from any experimental group of rats, indicating that glutamate release at CA3-CA1 synapses is not acutely regulated by $\mathrm{E}_{2}$ (Fig. $5 B$; Table 2).

The lack of acute effect of $\mathrm{E}_{2}$ on $\mathrm{Pr}$, particularly in $\mathrm{OVX}_{\text {Control }}$ $+\mathrm{E}_{2}$ rats, is at odds with a recent study conducted on OVX rats
B

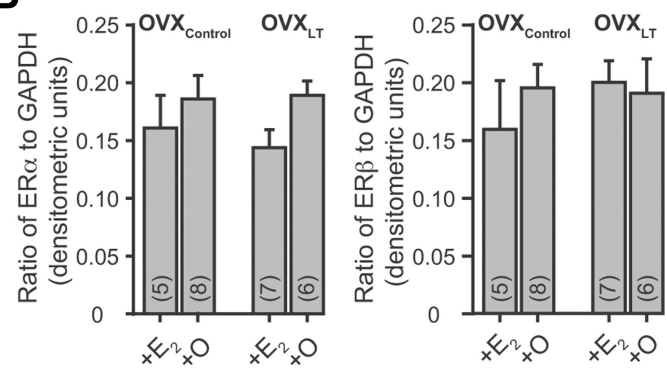

Figure 3. Protein levels of $E R \alpha$ and $E R \beta$ are not altered by ovarian hormone loss or in vivo $E_{2}$ treatment. $\boldsymbol{A}$, Representative plotted average values \pm SEM for each treatment group of rats. $\boldsymbol{B}$, Summary bar graphs of the relative levels of protein expression for $E R \alpha$ (left) and $E R \beta$ (right), normalized to GAPDH.
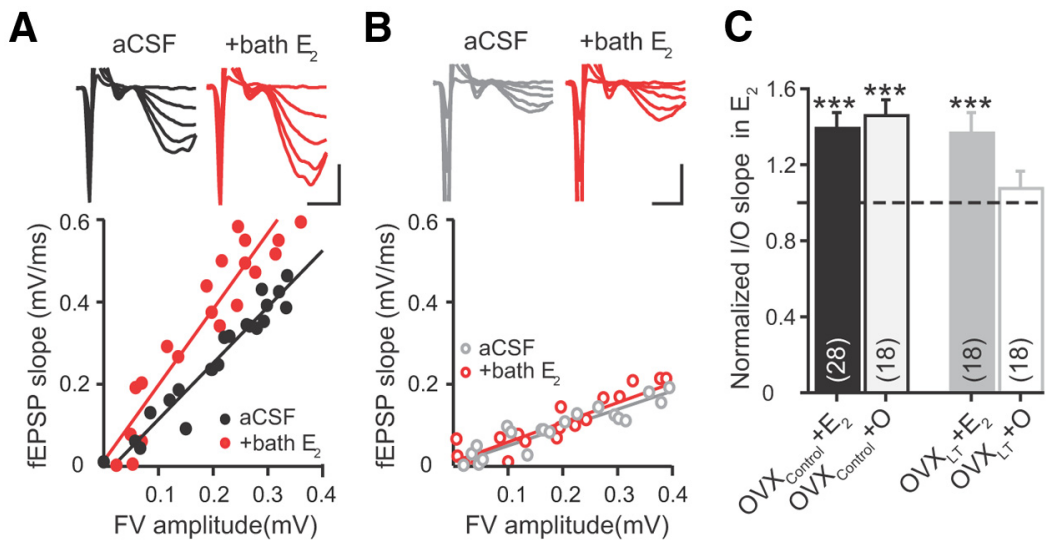

Figure 4. Acute effect of $\mathrm{E}_{2}$ on synaptic transmission. $\boldsymbol{A}, \boldsymbol{B}$, Top, Voltage traces from a $\mathrm{OVX}_{\text {Control }}+\mathrm{E}_{2}(\boldsymbol{A})$ and an $\mathrm{OVX}_{\mathrm{LT}}+0$ rat OVX controlvalues). Numbers in the parenthes dente the $\mathrm{OVX}_{\text {control }}+\mathrm{E}_{2}$, three rats, 15 slices; $\mathrm{OVX}_{\text {control }}+0$, three rats, 10 slices; $0 \mathrm{VX}_{\mathrm{LT}}+\mathrm{E}_{2}$, four rats, 9 slices; and $0 \mathrm{VX}_{\mathrm{LT}}+0$, four rats, 10 slices. ${ }^{* * *} p \leq 0.001$ following bath application of $\mathrm{E}_{2}$ (relative to baseline recordings in control aCSF).

that received comparable in vivo $\mathrm{E}_{2}$ treatment (Smejkalova and Woolley, 2010). This study reported that bath application of $\mathrm{E}_{2}$ increased $\mathrm{Pr}$ at a subset of CA3-CA1 synapses with low initial Pr (high initial PPF). Because the $\mathrm{Cs}^{+}$-based internal solution we used to isolate AMPA receptor-mediated EPSCs differs substantially from the $\mathrm{K}^{+}$-based internal solution used by Smejkalova and Woolley (2010), we first verified that changes in Pr could be detected under our recording conditions, by bath applying 4-aminopyridine (4-AP; $100 \mu \mathrm{M}$ ) to block primarily $\mathrm{K}_{\mathrm{V}} 1$ channels located on the axons and presynaptic terminals of CA3 pyramidal neurons (Monaghan et al., 2001). In contrast to $\mathrm{E}_{2}$, 4-AP significantly increased the amplitude of $\mathrm{EPSC}_{1}$ and reduced PPF (Fig. 5C). 4-AP also significantly increased $\mathrm{CV}^{-2}$ of $\mathrm{EPSC}_{1}$ amplitude (normalized $\mathrm{CV}^{-2}$ in 4-AP: $5.00 \pm 1.22, p<0.01 ; n=$ 10). These changes are consistent with the well documented effects of 4-AP to increase Pr at CA3-CA1 synapses (Buckle and Haas, 1982; Hjelmstad et al., 1997), demonstrating that changes in presynaptic function are readily detected using our internal solution. Next, we performed additional analyses on data from OVX ${ }_{\text {control }}+E_{2}$ rats to ensure that an acute effect of $E_{2}$ on Pr at a subset of CA3-CA1 synapses was not overlooked. Figure 5Di shows a plot of the relative effect of bath-applied $\mathrm{E}_{2}$ on $\mathrm{EPSC}_{1}$ 
A
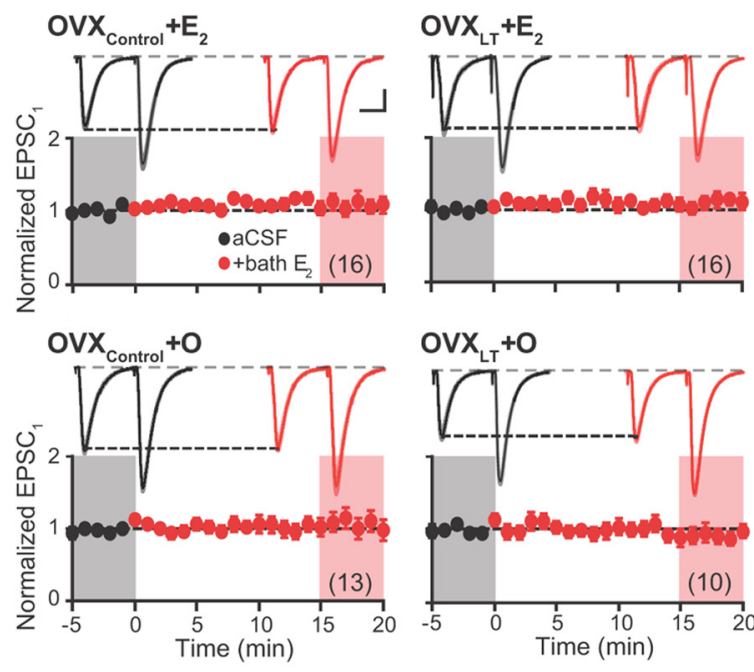

B
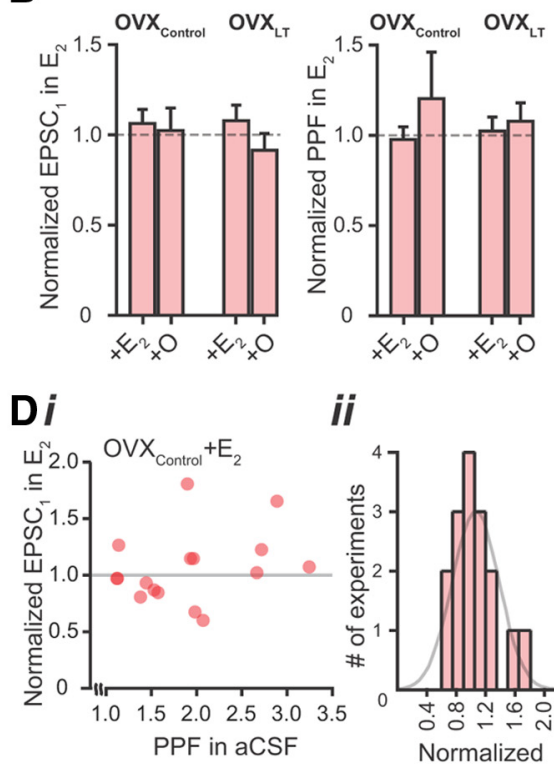

ii

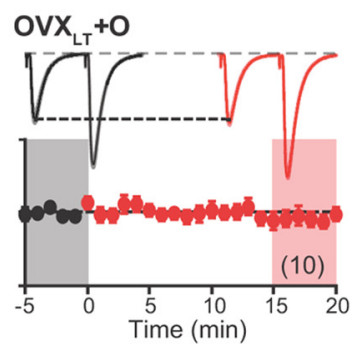

C

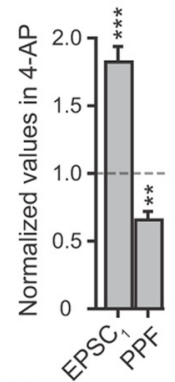

iii

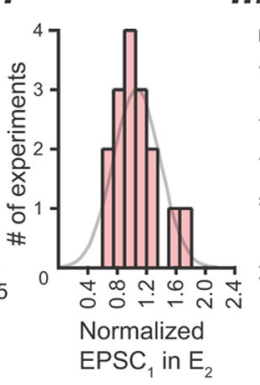

PPF $>1.91$

ن 1.47

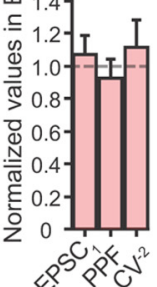

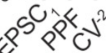

Figure 5. $E_{2}$ does not acutely affect $\operatorname{Pr}$ at $C A 3-C A 1$ synapses. $A$, Summary time course plots of normalized EPSC ${ }_{1}$ amplitude in control aCSF (black) followed by bath application of $\mathrm{E}_{2}$ (red; starts at time 0 ). Data are binned into $1 \mathrm{~min}$ intervals. Above each time course plot are representative current traces from one neuron in each experimental group. The solid traces are the average of 15 consecutive current traces; SEMs for the averaged traces are superimposed in light shading. The current traces used for averaging were taken at time points highlighted with gray and red shadings in the time course plots. Calibration: $50 \mathrm{pA}, 20 \mathrm{~ms}$. The numbers in parentheses indicate the numbers of independent CA3-CA1 pathways tested, from the following: $\mathrm{OVX}_{\text {Control }}+\mathrm{E}_{2}$, six rats, nine slices; $0 \mathrm{VX} \mathrm{Control}_{\text {( }}+0$, four rats, eight slices; $0 \mathrm{VX} \mathrm{LT}_{\mathrm{LT}}+\mathrm{E}_{2}$, four rats, eight slices; and $O V X_{\mathrm{LT}}+0$, three rats, eight slices. $B$, Summary bar graphs of normalized EPSC amplitude (left) and PPF (right) in the presence of $E_{2}$. $C$, Summary bar graphs of normalized EPSC ${ }_{1}$ amplitude and PPF in the presence of 4-AP. Data were collected from seven rats, nine slices. Di, $\boldsymbol{A}$, Normalized EPSC ${ }_{1}$ amplitude in the presence of $E_{2}$ plotted against initial PPF for individual experiments performed on $\mathrm{OVX}_{\text {Control }}+\mathrm{E}_{2}$ rats. Dii, Histogram of normalized EPSC amplitude in $E_{2}$. The data were fit with a Gaussian distribution indicated in gray. Diii, Summary bar graphs of normalized values for EPSC amplitude, PPF, and CV $^{-2}$ for experiments that had initial PPF values greater than the median (1.91) for this group.

amplitude versus PPF of EPSCs recorded in control aCSF for individual experiments. No clear relation was found between these two measures. The histogram of normalized $\mathrm{EPSC}_{1}$ amplitude in $\mathrm{E}_{2}$ shows a single distribution, suggesting a single popu-

lation of CA3-CA1 synapses that respond similarly to bathapplied $\mathrm{E}_{2}$ (Fig. 5Dii). We also evaluated the relative effect of bath-applied $\mathrm{E}_{2}$ on $\mathrm{EPSC}_{1}$ amplitude, $\mathrm{PPF}$, or $\mathrm{CV}^{-2}$ for synapses that exhibited PPF above the median for $\mathrm{OVX}_{\text {Control }}+\mathrm{E}_{2}$ rats (median $=1.91 ; n=8)$, and found no acute effect of $\mathrm{E}_{2}$ on these measures (Fig. 5Diii). Thus, we cannot demonstrate an acute effect of $E_{2}$ on Pr at a subset of CA3-CA1 synapses.

\section{$\mathrm{E}_{2}$ 's acute increase of the I/O (fEPSP-FV) slope reflects postsynaptic mechanisms}

Because $\mathrm{E}_{2}$ does not acutely increase Pr at CA3-CA1 synapses, the increase in the I/O slope following bath application of $\mathrm{E}_{2}$ (Fig. 4) most likely reflects postsynaptic mechanisms. To verify, we performed whole-cell current-clamp recordings of mixed AMPA and NMDA receptor-mediated EPSPs from CA1 pyramidal neurons, first in control aCSF followed by bath application of $\mathrm{E}_{2}$. Neurons were maintained at $-65 \mathrm{mV}$ throughout the recordings with bias current injections. No significant differences were found in the passive membrane properties such as input resistance and resting membrane potential across groups, consistent with previous reports (Wong and Moss, 1992; Woolley et al., 1997; Wu et al., 2011;Table 3). Glutamate release was evoked with a paired-pulse protocol, with the stimulus intensity set at a level so that the EPSP ${ }_{1}$ was of comparable amplitude across groups $\left(\mathrm{OVX}_{\text {Control }}+\mathrm{E}_{2}: 2.5 \pm 0.2 \mathrm{mV}, n=17 ; \mathrm{OVX}_{\text {Control }}+\mathrm{O}: 2.9 \pm\right.$ $0.4 \mathrm{mV}, n=20 ; \mathrm{OVX}_{\mathrm{LT}}+\mathrm{E}_{2}: 2.9 \pm 0.2 \mathrm{mV}, n=19 ; \mathrm{OVX}_{\mathrm{LT}}+\mathrm{O}$ : $2.4 \pm 0.2 \mathrm{mV}, n=19)$. There was a significant effect of the post-OVX interval without ovarian hormones, but not in vivo $\mathrm{E}_{2}$ treatment, on the stimulus intensity used $\left(F_{(1,66)}=8.088, p<\right.$ $0.01)$. On average, the stimulus intensity required for $\mathrm{OVX}_{\mathrm{LT}}$ rats was twice that required for $\mathrm{OVX}_{\text {Control }}$ rats $\left(\mathrm{OVX}_{\text {Control }}: 7 \pm 1\right.$ $\left.\mu \mathrm{A}, n=37 ; \mathrm{OVX}_{\mathrm{LT}}: 13 \pm 2 \mu \mathrm{A}, n=38 . p<0.01\right)$, consistent with the fEPSP and voltage-clamp recording results. Representative EPSPs recorded from each experimental group of rats are shown in Figure 6A. Table 3 summarizes measurements of EPSP kinetics as well as the degree of temporal summation (or PPF) of EPSPs evoked at $50 \mathrm{~ms}$ intervals. No significant difference was found in any of these measures.

Bath application of $\mathrm{E}_{2}$ significantly increased the amplitude of EPSP $_{1}$ recorded from OVX $\mathrm{O}_{\text {Control }}+\mathrm{E}_{2}, \mathrm{OVX}_{\text {Control }}+\mathrm{O}$, and $\mathrm{OVX}_{\mathrm{LT}}+\mathrm{E}_{2}$ rats by comparable percentages (Fig. 6A, $B$; Table 4). In all cases, the increase in $\mathrm{EPSP}_{1}$ amplitude was accompanied by an increase in EPSP initial slope (Fig. 6C). PPF and EPSP kinetics were not affected by $\mathrm{E}_{2}$ application (Table 4 ). In contrast, $\mathrm{E}_{2}$ had no acute effect on the EPSPs recorded from $\mathrm{OVX}_{\mathrm{LT}}+\mathrm{O}$ rats (Fig. $6 A-C$; Table 4). These results demonstrate that $E_{2}$ acutely increases synaptic strength by increasing the postsynaptic membrane response to glutamate.

\section{$E_{2}$ 's acute increase of EPSPs depends on postsynaptic $\mathrm{Ca}^{2+}$ influx}

A rise in the postsynaptic $\left[\mathrm{Ca}^{2+}\right]$ at $\mathrm{CA} 3-\mathrm{CA} 1$ synapses is known to activate several signaling processes that can lead to an increase in the postsynaptic membrane response to glutamate (Wyllie and Nicoll, 1994; Wyllie et al., 1994; Barria et al., 1997; Carroll et al., 1998; Shi et al., 1999). To determine whether $\mathrm{E}_{2}$ 's acute increase of EPSPs is $\mathrm{Ca}^{2+}$ dependent, CA1 pyramidal neurons were patched with a $\mathrm{K}^{+}$-based internal solution containing BAPTA (5 $\mathrm{mM}$ )-a high affinity $\mathrm{Ca}^{2+}$ chelator-to rapidly buffer intracellular $\mathrm{Ca}^{2+}$. These experiments were performed on $\mathrm{OVX}_{\text {Control }}+\mathrm{E}_{2}$ and $\mathrm{OVX}_{\mathrm{Control}}+\mathrm{O}$ rats. Bath application of $\mathrm{E}_{2}$ did not significantly affect the amplitude or the initial slope of EPSP $_{1}$ recorded using the BAPTA-containing $\mathrm{K}^{+}$-based internal solution, dem- 
Table 2. Measurements of presynaptic function in control aCSF followed by bath application of $E_{2}$

\begin{tabular}{|c|c|c|c|c|c|c|}
\hline & \multicolumn{2}{|c|}{$\mathrm{EPSC}_{1}$ amplitude (pA) } & \multicolumn{2}{|l|}{$\mathrm{CV}^{-2}$} & \multicolumn{2}{|l|}{ PPF } \\
\hline & $\mathrm{aCSF}$ & + bath $E_{2}$ & $\mathrm{aCSF}$ & + bath $E_{2}$ & $\mathrm{aCSF}$ & + bath $\mathrm{E}_{2}$ \\
\hline $0 \mathrm{VXX}_{\text {Control }}+\mathrm{E}_{2}(16)$ & $-137.6 \pm 21.7$ & $-147.2 \pm 23.8$ & $18.5 \pm 2.9$ & $27.9 \pm 8.0$ & $1.92 \pm 0.17$ & $1.82 \pm 0.17$ \\
\hline $0 \mathrm{VX}_{\text {Control }}+0(13)$ & $-120.9 \pm 15.4$ & $-125.9 \pm 20.5$ & $15.2 \pm 3.4$ & $14.7 \pm 2.8$ & $2.16 \pm 0.28$ & $2.40 \pm 0.50$ \\
\hline $0 \mathrm{VX}_{\mathrm{LT}}+\mathrm{E}_{2}(16)$ & $-145.2 \pm 13.4$ & $-163.3 \pm 19.5$ & $16.4 \pm 2.7$ & $25.3 \pm 7.5$ & $1.74 \pm 0.13$ & $1.74 \pm 0.14$ \\
\hline $0 \mathrm{VX}_{\mathrm{LT}}+0(10)$ & $-146.8 \pm 17.8$ & $-136.3 \pm 28.4$ & $12.1 \pm 1.2$ & $16.4 \pm 3.6$ & $1.83 \pm 0.15$ & $1.92 \pm 0.16$ \\
\hline
\end{tabular}

The numbers in parentheses indicate the numbers of independent $\mathrm{CA3}-\mathrm{CA} 1$ pathways tested for individual groups, from the following number of rats and hippocampal slices: $0 \mathrm{VX} \mathrm{Control}_{\mathrm{C}}+\mathrm{E}_{2}$, six rats, nine slices; $0 \mathrm{VX} \mathrm{Control}_{\mathrm{C}}+0$, four rats, eight slices; $0 \mathrm{VX}_{\mathrm{LT}}+\mathrm{E}_{2}$, four rats, eight slices; and $\mathrm{OVX} \mathrm{LT}_{\mathrm{LT}}+0$, three rats, eight slices.

Table 3. Passive membrane properties and EPSP kinetics in control aCSF

\begin{tabular}{|c|c|c|c|c|c|c|c|}
\hline & $R_{\text {input }}(\mathrm{M} \Omega)$ & $\mathrm{RMP}(\mathrm{mV})$ & $\begin{array}{l}\text { EPSP }_{1} \text { half- } \\
\text { width (ms) }\end{array}$ & $\begin{array}{l}\mathrm{EPSP}_{1}+\mathrm{EPSP}_{2} \\
\text { half-width (ms) }\end{array}$ & $\begin{array}{l}\mathrm{EPSP}_{1} \text { initial } \\
\text { slope }(\mathrm{V} / \mathrm{s})\end{array}$ & $\begin{array}{l}20-80 \% \text { rise } \\
\text { time (ms) }\end{array}$ & PPF \\
\hline $\mathrm{OVX}_{\text {Control }}+\mathrm{E}_{2}$ & $128.5 \pm 16.2(8)$ & $-56.7 \pm 1.8$ & $50.2 \pm 2.9(15)$ & $96.5 \pm 2.8(13)$ & $0.42 \pm 0.04(16)$ & $4.9 \pm 0.2(14)$ & $1.99 \pm 0.15(15)$ \\
\hline $0 \mathrm{VX}_{\text {Control }}+0$ & $94.1 \pm 11.1(10)$ & $-56.9 \pm 1.5$ & $53.6 \pm 2.9(20)$ & $100.1 \pm 2.5(19)$ & $0.46 \pm 0.06(19)$ & $5.0 \pm 0.2(17)$ & $2.18 \pm 0.43(19)$ \\
\hline $0 \mathrm{VX} \mathrm{LT}_{\mathrm{LT}}+\mathrm{E}_{2}$ & $106.7 \pm 10.0(11)$ & $-58.4 \pm 1.3$ & $48.7 \pm 2.2(19)$ & $98.0 \pm 2.6(19)$ & $0.52 \pm 0.05(19)$ & $4.8 \pm 0.2(16)$ & $2.04 \pm 0.09(19)$ \\
\hline $0 \mathrm{VX}_{\mathrm{LT}}+0$ & $104.0 \pm 12.9(10)$ & $-61.2 \pm 1.5$ & $47.9 \pm 3.0(19)$ & $95.2 \pm 3.0(17)$ & $0.43 \pm 0.04(19)$ & $4.4 \pm 0.2(17)$ & $2.12 \pm 0.18(18)$ \\
\hline
\end{tabular}

The numbers in the parentheses for " $R_{\text {input }}$ " denote the numbers of neurons recorded for individual groups; these also apply to "RMP", or resting membrane potential. The numbers in the parentheses for EPSP measures refer to the numbers of independent CA3-CA1 pathways tested for individual groups, from the following number of rats and hippocampal slices: $0 \mathrm{VX}_{\text {Control }}+\mathrm{E}_{2}$, three rats, 8 slices; $0 \mathrm{VX}$ Control +0 , five rats, 10 slices; $0 \mathrm{VX} \mathrm{LT}_{\mathrm{LT}}+\mathrm{E}_{2}$, four rats, 11 slices; and $0 \mathrm{VX}$ LT +0 , three rats, 10 slices. EPSP $1+$ EPSP $_{2}$ half-width reflects the duration from EPSP ${ }_{1}$ half-peak to EPSP $_{2}$ half-decay.
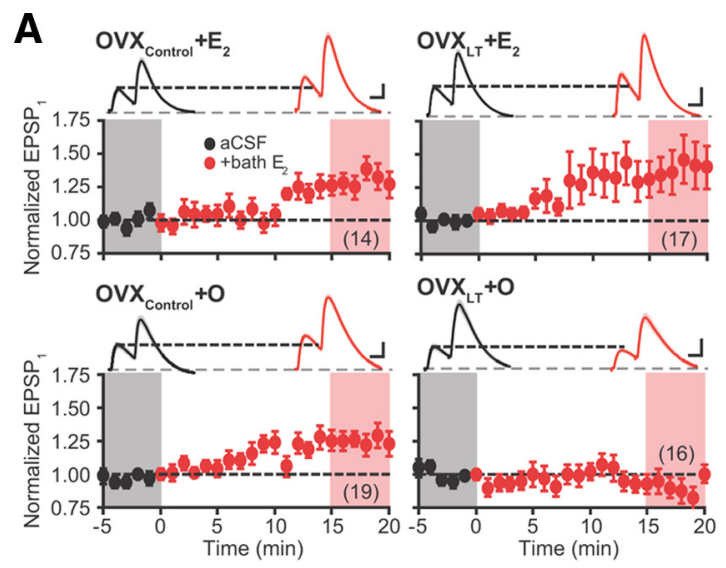

B

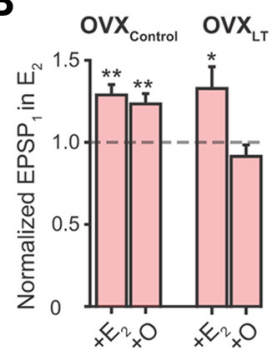

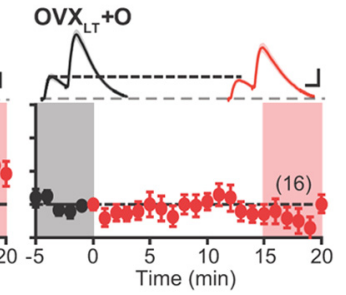

C

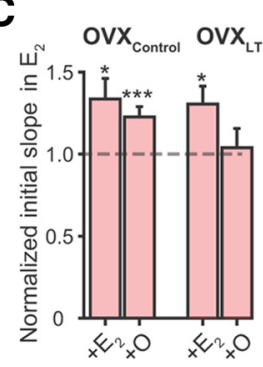

Figure 6. $E_{2}$ acutely increases EPSPs. $\boldsymbol{A}$, Summary time course plots of normalized EPSP amplitude in control aCSF followed by bath application of $E_{2}$ (red; starts at time 0 ). Data are binned into $1 \mathrm{~min}$ intervals. Above each time course plot are representative voltage traces (the average of 15 consecutive voltage traces; SEMs for the averaged traces are superimposed) acquired in control aCSF (black) and in $E_{2}$ (red) for one neuron in each experimental group. The voltage traces used for averaging were taken at time points highlighted with gray and red shadings in the time course plots. Calibrations: " $0 \mathrm{VX}_{\text {Control }}+\mathrm{E}_{2}$ " and " $0 \mathrm{VX} \mathrm{C}_{\text {Control }}+0,{ }^{\prime} 1 \mathrm{mV}, 25$ $m s$; "OVX $X_{\mathrm{LT}}+\mathrm{E}_{2}$ " and "OVX $\mathrm{LT}+0$," $2 \mathrm{mV}, 25 \mathrm{~ms}$. The numbers in parentheses indicate the numbers of independent CA3-CA1 pathways tested, from the following: $\mathrm{OVX}_{\text {Control }}+\mathrm{E}_{2}$, three rats, 8 slices; $0 \mathrm{VX} \mathrm{Control}+0$, five rats, 10 slices; $0 \mathrm{VX} \mathrm{LT}_{\mathrm{LT}}+\mathrm{E}_{2}$, four rats, 11 slices; and $0 \mathrm{VX} \mathrm{LT}_{\mathrm{LT}}+0$, three rats, 10 slices. $\boldsymbol{B}, \boldsymbol{C}$, Summary bar graphs of normalized EPSP ${ }_{1}$ amplitude $(\boldsymbol{B})$ and initial slope $(\boldsymbol{C})$ in the presence of $\mathrm{E}_{2} \cdot{ }^{*} p \leq 0.05,{ }^{* *} p \leq 0.01$, and ${ }^{* * *} p \leq 0.001$, respectively, following bath application of $\mathrm{E}_{2}$ (relative to baseline recordings in control aCSF).

onstrating that $\mathrm{E}_{2}$ 's acute increase of EPSPs requires a rise in the postsynaptic $\left[\mathrm{Ca}^{2+}\right]$ during synaptic activity (Fig. $7 A$; Table 5).

Previous $\mathrm{Ca}^{2+}$ imaging studies showed that $>80 \%$ of $\mathrm{Ca}^{2+}$ signals associated with subthreshold EPSPs in CA1 spines is me-

diated by NMDA receptor activation (Yuste et al., 1999; Kovalchuk et al., 2000). Thus, we evaluated whether $\mathrm{Ca}^{2+}$ influx through NMDA receptors is required for $\mathrm{E}_{2}$ to acutely increase EPSPs. When the NMDA receptor blocker D-AP5 $(50 \mu \mathrm{M})$ was present throughout the experiment, bath application of $E_{2}$ still significantly increased the EPSPs (Fig. 7B; Table 5). The percentage increases for both EPSP initial slope and amplitude were comparable to measurements obtained in the absence of D-AP5 (Fig. $6 B, C$ vs Fig. $7 B$ ), indicating that NMDA receptor-mediated $\mathrm{Ca}^{2+}$ influx is not necessary for $\mathrm{E}_{2}$ to increase EPSPs. The L-type $\left(\mathrm{Ca}_{\mathrm{V}} 1\right)$ and the R-type $\left(\mathrm{Ca}_{\mathrm{V}} 2.3\right) \mathrm{Ca}^{2+}$ channels are expressed on the dendrites and spines of CA1 pyramidal neurons (Hell et al., 1993; Tippens et al., 2008; Parajuli et al., 2012), although their activation does not contribute appreciably to spine $\mathrm{Ca}^{2+}$ during subthreshold EPSPs (Kovalchuk et al., 2000) or membrane depolarization (Bloodgood and Sabatini, 2007). Nonetheless, bath application of nimodipine $(10 \mu \mathrm{M})$ and $\mathrm{Ni}^{2+}(100 \mu \mathrm{M})$, blockers of the $\mathrm{Ca}_{\mathrm{V}} 1$ and $\mathrm{Ca}_{\mathrm{V}} 2.3$ channels, respectively, in addition to D-AP5, occluded $\mathrm{E}_{2}$ 's acute increase of EPSPs (Fig. 7C; Table 5). These results demonstrate that $\mathrm{Ca}^{2+}$ influx through $\mathrm{Ca}_{\mathrm{V}} 1$ and/or $\mathrm{Ca}_{\mathrm{V}} 2.3$ channels is required for $\mathrm{E}_{2}$ to acutely increase EPSPs.

\section{Bath application of $E_{2}$ increases AMPA but not NMDA receptor activity}

The increase in the initial slopes of both fEPSPs measured extracellularly (Fig. 4C) and EPSPs recorded from individual neurons (Fig. $6 B$ ) following bath application of $E_{2}$ suggests that $E_{2}$ acutely increases AMPA receptor activity. To test this hypothesis, we performed experiments on $\mathrm{OVX}_{\text {Control }}+\mathrm{E}_{2}$ rats. Whole-cell voltage-clamp experiments of AMPA receptor-mediated EPSCs were made from CA1 pyramidal neurons in the presence of D-AP5, using a $\mathrm{Cs}^{+}$-based internal solution without D600 to block $\mathrm{Ca}_{\mathrm{V}}$ channels and BAPTA to chelate $\mathrm{Ca}^{2+}$ postsynaptically. Glutamate release was triggered with one synaptic stimulus. The kinetics of EPSCs recorded with this internal solution were comparable to those recorded with D600 and BAPTA present (20$80 \%$ rise time: $1.99 \pm 0.11 \mathrm{~ms}$; half-width $11.69 \pm 0.84 \mathrm{~ms} ; n=9$; Table 1). Bath application of $\mathrm{E}_{2}$ significantly increased the amplitude of EPSC ( $a C S F,-188.2 \pm 14.9 \mathrm{pA} ;+$ bath $E_{2},-224.0 \pm 20.9$ pA; $n=9$. $p<0.05$; Fig. 8$)$. These results demonstrate that the acute increase in EPSPs following bath application of $\mathrm{E}_{2}$ reflects 
Table 4. EPSP in control aCSF followed by bath application of $E_{2}$

\begin{tabular}{|c|c|c|c|c|c|c|c|c|c|c|}
\hline & \multicolumn{3}{|c|}{$\mathrm{EPSP}_{1}$ amplitude $(\mathrm{mV})$} & \multicolumn{3}{|l|}{ PPF } & \multicolumn{2}{|c|}{ EPSP ${ }_{1}$ half-width (ms) } & \multicolumn{2}{|c|}{$20-80 \%$ rise time (ms) } \\
\hline & $\mathrm{aCSF}$ & $+\mathrm{E}_{2}$ & $\%$ in $E_{2}$ & $\mathrm{aCSF}$ & $+\mathrm{E}_{2}$ & $\%$ in $E_{2}$ & aCSF & $+\mathrm{E}_{2}$ & $\mathrm{aCSF}$ & $+\mathrm{E}_{2}$ \\
\hline & ) & $3 \pm 0$ & $129 \pm 6$ & $94=$ & $1.68 \pm 0.16$ & $87 \pm 7$ & 48.2 & $48.2=$ & $4.9=$ & $4.6 \pm 0.2$ \\
\hline+0 & $2.9 \pm$ & $3.7 \pm 0.6^{* *}$ & $123 \pm 7$ & $1.86 \pm$ & $1.77 \pm 0.32$ & $92 \pm 5$ & $53.1 \pm 3.0(19)$ & $55.8 \pm$ & $5.0 \pm$ & $5.5 \pm 0$ \\
\hline $\mathrm{OVX}_{\mathrm{LT}}+\mathrm{E}_{2}$ & $3.1 \pm 0.2(17)$ & $4.3 \pm 0.6^{*}$ & $133 \pm 13$ & $1.98 \pm 0.11(13)$ & $1.89 \pm 0.16$ & $95 \pm 5$ & $49.5 \pm 2.3(17)$ & $51.2 \pm 2.8$ & $4.8 \pm 0.2(14)$ & $5.0 \pm 0.3$ \\
\hline $\mathrm{OVX}_{\mathrm{LT}}+0$ & $2.5 \pm 0.2(16)$ & $2.3 \pm 0.2$ & $92 \pm 7$ & $2.11 \pm 0.20(16)$ & $2.23 \pm 0.30$ & $110 \pm 7$ & $49.1 \pm 3.6(15)$ & $55.0 \pm 4.6$ & $4.5 \pm 0.2(14)$ & $4.7 \pm 0.3$ \\
\hline
\end{tabular}

${ }^{*} p \leq 0.05$ and ${ }^{* *} p \leq 0.01$, respectively, as compared with measures made in control aCSF for the same experimental group of rats. The numbers in the parentheses for EPSP amplitude measures refers to the numbers of independent

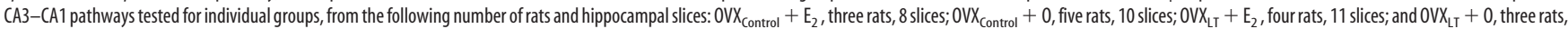
10 slices. The numbers in the parentheses for PPF measures are fewer than those for EPSP a mplitude measures, as in some cases the second synaptic stimulus evoked APs instead of EPSPs following bath application of $E_{2}$, and in others EPSPS were evoked with one rather than two synaptic stimuli. These experiments yielded no data on EPSP 2 hence no PPF values.

A

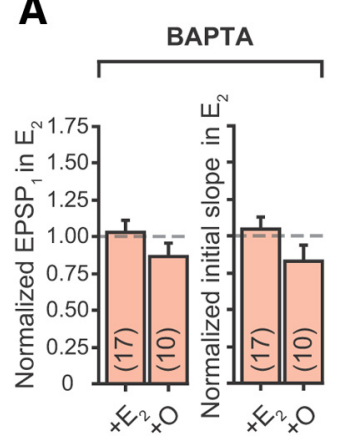

B

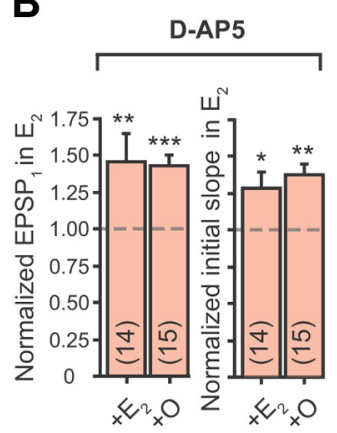

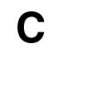

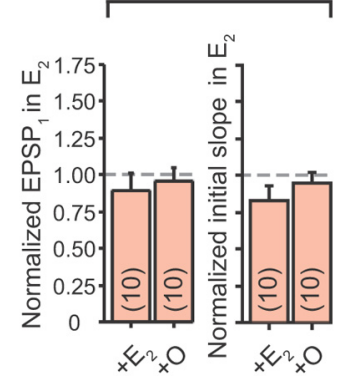

Figure 7. $E_{2}$ 's acute effect on EPSPs depends on postsynaptic $\mathrm{Ca}^{2+}$ influx during synaptic activity. $A-C$, Summary bar graphs of normalized EPSP amplitudes and initial slopes in $\mathrm{E}_{2}$ for "OVX $\mathrm{OV}_{\text {control }}+\mathrm{E}_{2}$ " and "OVX $\mathrm{O}_{\text {Control }}+0$ " rats, recorded with BAPTA in the $\mathrm{K}^{+}$-based internal solution $(\boldsymbol{A})$; in the presence of $\mathrm{D}$-AP5 with normal $\mathrm{K}^{+}$-based internal solution without BAPTA $(\boldsymbol{B})$; and in the presence of $\mathrm{D}-\mathrm{AP5}, \mathrm{Ni}^{2+}$, and nimodipine (C). For BAPTA experiments, the numbers of independent CA3-CA1 pathways tested per group (in parentheses) were collected from the following: $0 \mathrm{VX}_{\text {control }}+\mathrm{E}_{2}$, three rats, nine slices; $0 \mathrm{VX}$ control +0 , two rats, five slices. For D-AP5 experiments: $0 \mathrm{VXX}_{\text {control }}+\mathrm{E}_{2}$, three rats, eight slices; $\mathrm{OVX}_{\text {Control }}+0$, two rats, nine slices. For D-AP5 $+\mathrm{Ni}^{2+}+$ nimodipine experiments: $0 \mathrm{VX}_{\text {control }}+\mathrm{E}_{2}$, two rats, five slices; $0 \mathrm{VX}_{\text {control }}+0$, two rats, five slices. ${ }^{*} p \leq 0.05,{ }^{* *} p \leq 0.01$, and ${ }^{* * *} p \leq 0.001$, respectively, following bath application of $\mathrm{E}_{2}$ (relative to baseline recordings in control aCSF).

an increase in the postsynaptic AMPA receptor activity in a $\mathrm{Ca}^{2+}$-dependent manner.

Finally, we tested whether bath application of $\mathrm{E}_{2}$ increases NMDA receptor activity. NMDA receptor-mediated EPSCs were recorded in the presence of CNQX $(25 \mu \mathrm{M})$ to block AMPA receptors, using the $\mathrm{Cs}^{+}$-based internal solution without D600 and BAPTA. Neurons were held at $-35 \mathrm{mV}$, and dependence of EPSCs on NMDA receptor activation was verified by occlusion of EPSCs with D-AP5 at the end of the experiments. Representative current traces of EPSCs made under this recording condition are shown in Figure $8 A$. NMDA receptor-mediated EPSCs were kinetically distinct from those mediated by AMPA receptors (20$80 \%$ rise time, $5.82 \pm 0.61 \mathrm{~ms}$; half-width, $62.73 \pm 4.35 \mathrm{~ms} ; n=$ 8). Bath application of $E_{2}$ did not affect NMDA receptormediated EPSCs $\left(a C S F,-65.4 \pm 10.7 \mathrm{pA}\right.$; +bath $E_{2},-56.5 \pm$ 7.6; $n=8$. Fig. 8). These results demonstrate that $\mathrm{E}_{2}$ does not acutely regulate NMDA receptors.

\section{Discussion}

Our central findings are that long-term ovarian hormone loss markedly reduced synaptic strength and abolished $\mathrm{E}_{2}$ 's acute regulation of synaptic strength. In vivo $\mathrm{E}_{2}$ treatment increased synaptic strength when initiated $7 \mathrm{~d}$ following OVX but not after 5 months of delay. Delayed $\mathrm{E}_{2}$ treatment was not completely ineffective, as it did restore the acute $\mathrm{E}_{2}$ sensitivity. Thus, the efficacy of in vivo $\mathrm{E}_{2}$ treatment was diminished by, but not fully abolished after, 5 months of ovarian hormone loss. While the $\mathrm{E}_{2}$ treatment regimen tested here is briefer than that used in surgically menopausal women, these results nevertheless provide a framework for understanding synaptic dysfunctions arising from ovarian hor- mone loss that may contribute to surgical menopause-related cognitive impairment and the diminished efficacy for delayed $\mathrm{E}_{2}$ therapy to restore cognitive functions.

Synaptic transmission, a process involving presynaptic neurotransmitter release and postsynaptic neurotransmitter receptor activation, reflects the first step of signal transfer between most central neurons. A change in synaptic transmission directly alters the level of postsynaptic depolarization, affecting not only AP generation in the postsynaptic neuron but also information storage within individual synapses (or synaptic plasticity, thought to represent cellular memory) by affecting postsynaptic $\mathrm{Ca}^{2+}$ influx. At CA3-CA1 synapses, long-term potentiation, manifested as a lasting increase in synaptic strength, has been shown to mediate certain forms of hippocampusdependent memory (Gruart et al., 2006; Pastalkova et al., 2006; Whitlock et al., 2006). The reduced synaptic strength at CA3-CA1 synapses that we described for OVX rats would significantly impair hippocampal function, making it a plausible cellular mechanism underlying cognitive impairment in OVX animals (Gibbs, 2000; Markowska and Savonenko, 2002; Daniel et al., 2006) and surgically menopausal women (Nappi et al., 1999; Farrag et al., 2002; Rocca et al., 2007). Consistent with this interpretation, a reduced synaptic strength at CA3-CA1 synapses has been reported in rodent models of Alzheimer's disease (Ricoy et al., 2011) and normal brain aging (Barnes et al., 1992) that exhibit hippocampus-dependent learning and memory deficits (Gallagher and Pelleymounter, 1988; Kadar et al., 1990; Puoliväli et al., 2002). Previous studies have also shown that pharmacological (Arai et al., 2002; Knafo et al., 2012) or genetic manipulations (Tang et al., 1999) that increase synaptic strength at CA3-CA1 synapses enhance hippocampus-dependent learning and memory (Hampson et al., 1998; Tang et al., 1999; Knafo et al., 2012). Our finding that $\mathrm{E}_{2}$ treatment initiated shortly after OVX but not after 5 months of delay increases synaptic strength may thus explain in part why immediate (Sherwin, 1988; Phillips and Sherwin, 1992; Rocca et al., 2007) but not delayed $\mathrm{E}_{2}$ therapy following OVX protects against cognitive decline (Rocca et al., 2007).

Injecting $\mathrm{OVX}_{\text {Control }}$ rats with $\mathrm{E}_{2}$, using a protocol that elevates the circulating $\mathrm{E}_{2}$ level for $3 \mathrm{~d}$ before recording (Woolley and McEwen, 1993), results in an increased I/O slope (Fig. $1 B 1, C)$. This most likely reflects an increased level of AMPA receptor activity evoked by a given number of CA3 axons firing an $\mathrm{AP}$, because the initial slope of fEPSP primarily reflects AMPA 
Table 5. $\mathrm{E}_{2}$ 's acute increase of EPSPs is $\mathrm{Ca}^{2+}$ dependent

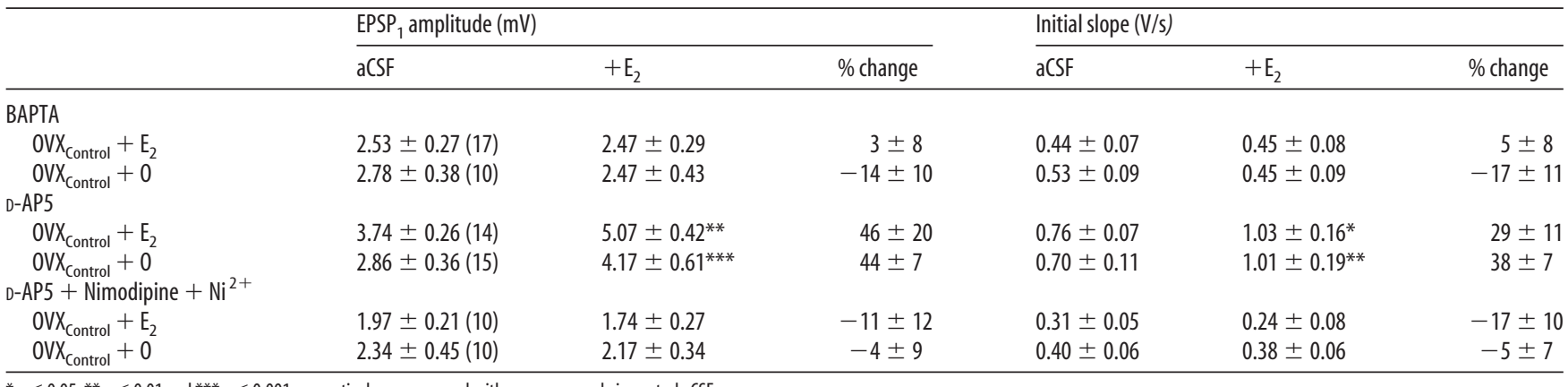

${ }^{*} p<0.05,{ }^{* *} p<0.01$ and ${ }^{* * *} p<0.001$, respectively, as compared with measures made in control aCSF.

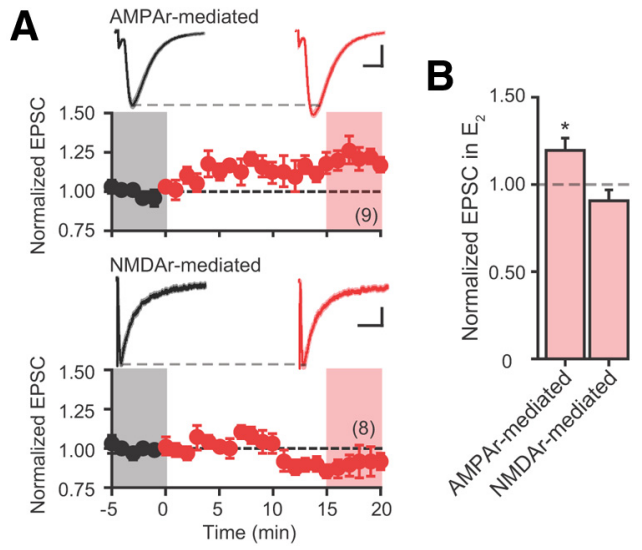

Figure 8. $E_{2}$ acutely increases AMPA but not NMDA receptor activity. $\boldsymbol{A}$, Summary time course plots of normalized AMPA receptor-mediated (top) and NMDA receptor-mediated (bottom) EPSC amplitude in control aCSF followed by bath application of $E_{2}$ (red; starts at time 0 ). Data are binned into $1 \mathrm{~min}$ intervals. Above each time course plot are representative current traces (the average of 15 consecutive current traces; SEMs for the averaged traces are superimposed) acquired in control aCSF (black) and in $E_{2}$ (red) for one neuron in each experiment. The current traces used for averaging were taken at time points highlighted with gray and red shadings in the time course plots. Calibrations: AMPA receptor-mediated: $50 \mathrm{pA}, 10 \mathrm{~ms}$; NMDA receptor-mediated: $10 \mathrm{pA}, 100 \mathrm{~ms}$. $\boldsymbol{B}$, Summary bar graphs of normalized EPSC amplitudes in the presence of $\mathrm{E}_{2} \cdot{ }^{*} p<0.05$ compared with aCSF values. AMPA receptor-mediated EPSCs were collected from three rats and six slices; NMDA receptor-mediated EPSCs, two rats and five slices.

receptor activation. An increased I/O slope at the CA3-CA1 synapses can arise from an increase in the following: (1) the amount of glutamate released per each bouton, resulting from an increase in $\mathrm{Pr}$ and/or the vesicular content of glutamate; (2) the density of CA1 synapses associated with each CA3 axon collateral; or (3) the postsynaptic sensitivity to glutamate, mediated by an increased function and/or density of AMPA receptors. We found that Pr at CA3-CA1 synapses is unaffected by ovarian hormone loss or subsequent in vivo $\mathrm{E}_{2}$ treatment. In the postnatal brain, vesicular glutamate transporter 1 (VGLUT1) is the predominant glutamate transporter (Nakamura et al., 2005), and the number of VGLUT1 determines vesicular content of glutamate (Wilson et al., 2005). The hippocampal protein level of VGLUT1 is unaffected by in vivo $\mathrm{E}_{2}$ treatment in OVX rats, suggesting no change in vesicular content (Waters et al., 2009). Collectively, these results suggest that the increased $\mathrm{I} / \mathrm{O}$ slope in $\mathrm{OVX}_{\text {Control }}+\mathrm{E}_{2}$ relative to $\mathrm{OVX}_{\mathrm{Control}}+\mathrm{O}$ rats is mediated by postsynaptic and not presynaptic changes. Indeed, in vivo $\mathrm{E}_{2}$ treatment in $\mathrm{OVX}$ rats increases the spine density (Gould et al., 1990) and the frequency of presynaptic CA3 boutons forming multiple synapses with dendritic spines (multiple synapse boutons) in the CA1 stratum radiatum (Woolley et al., 1996). These structural changes indicate an increased connectivity between individual CA3 and CA1 pyramidal neurons, and predict that $\mathrm{AP}$ firing by a given number of CA3 axons would activate more CA1 spines hence more AMPA receptors. In vivo $\mathrm{E}_{2}$ treatment has also been shown to increase the immunoreactivity for AMPA receptor subunit GluA1 (Liu et al., 2008; Waters et al., 2009) and the plasma membrane expression of GluA1 in the hippocampus (Liu et al., 2008). Both of these postsynaptic changes are expected to increase the I/O slope, and may account for the increased synaptic strength in $\mathrm{OVX}_{\text {Control }}$ rats that received in vivo $\mathrm{E}_{2}$ treatment.

Bath application of $E_{2}$ acutely increased the I/O slope and EPSPs in OVX rats. In contrast, $\mathrm{OVX}_{\mathrm{LT}}+\mathrm{O}$ rats that experienced 5 months of ovarian hormone loss and did not receive in vivo $\mathrm{E}_{2}$ treatment exhibited a loss of acute $\mathrm{E}_{2}$ sensitivity. These results are consistent with, and extend to, previous studies documenting $\mathrm{E}_{2}$ 's acute regulation of CA3-CA1 synaptic transmission (Wong and Moss, 1992; Foy et al., 1999; Bi et al., 2000; Fugger et al., 2001; Smejkalova and Woolley, 2010), demonstrating that the acute $\mathrm{E}_{2}$ sensitivity requires circulating $\mathrm{E}_{2}$ for maintenance. Our results from $\mathrm{OVX}_{\mathrm{LT}}+\mathrm{O}$ rats are in contrast to a recent report, which showed that $1 \mathrm{nM} \mathrm{E}_{2}$ acutely increased CA3-CA1 fEPSP in middle-aged (15-18 months old) OVX rats that experienced 6 months of ovarian hormone loss (Inagaki et al., 2012). These different results are likely due to different concentrations of $\mathrm{E}_{2}$ tested and the age of rats used (100 pM and 7 months old, respectively, in the present study).

$\mathrm{E}_{2}$ 's acute effect has been attributed to both presynaptic and postsynaptic changes. Smejkalova and Woolley (2010) reported that $100 \mathrm{pM} \mathrm{E}_{2}$ acutely increases EPSCs and Pr of glutamate release at a subset of CA3-CA1 synapses. We could not reproduce this result when we recorded AMPA receptor-mediated EPSCs using a $\mathrm{Cs}^{+}$-based internal solution that contained BAPTA and D600 to buffer $\mathrm{Ca}^{2+}$ and block postsynaptic $\mathrm{Ca}_{\mathrm{V}}$ channels, respectively. However, when BAPTA and D600 were omitted from the internal solution, bath application of $\mathrm{E}_{2}$ did increase AMPA receptor-mediated EPSCs. Chelating postsynaptic $\mathrm{Ca}^{2+}$ with BAPTA in the $\mathrm{K}^{+}$-based internal solution also occluded the increase in EPSPs following bath application of $E_{2}$. Our results thus indicate that $\mathrm{E}_{2}$ acts postsynaptically to increase synaptic strength in a $\mathrm{Ca}^{2+}$-dependent manner. This is consistent with previous studies that showed postsynaptic depolarization in response to iontophoretic application of AMPA (Wong and Moss, 1992), or pharmacologically isolated AMPA receptor-mediated EPSPs (Foy et al., 1999) and fEPSPs (Kramár et al., 2009) are increased by bath application of $\mathrm{E}_{2}$.

Space clamp errors are associated with using somatic patch clamp to control membrane potential in the dendrites and spines (Williams and Mitchell, 2008; Poleg-Polsky and Diamond, 
2011). Thus, the increase in AMPA receptor-mediated EPSCs recorded without D600 and BAPTA following bath application $\mathrm{E}_{2}$ most likely reflects voltage escape in the dendrites and synapses, causing activation of postsynaptic $\mathrm{Ca}_{\mathrm{V}}$ conductances (and the associated $\mathrm{Ca}^{2+}$-activated signaling processes to increase AMPA receptor activity) during synaptic activation. Indeed, the increase in EPSPs following bath application of $\mathrm{E}_{2}$ was occluded by blocking $\mathrm{Ca}_{\mathrm{V}} 1$ and $\mathrm{Ca}_{\mathrm{V}} 2.3$ channels and NMDA receptors, but not by blocking NMDA receptors alone, confirming that a $\mathrm{Ca}^{2+}$ activated signaling process associated with the postsynaptic $\mathrm{Ca}_{\mathrm{V}}$ channels mediates $\mathrm{E}_{2}$ 's acute regulation of CA3-CA1 synaptic transmission and AMPA receptor activity.

Bath application of $\mathrm{E}_{2}$ did not acutely increase the isolated NMDA-mediated EPSCs, in contrast to a previous study performed on hippocampal slices of male rats that found that bath application of $1 \mathrm{nM} \mathrm{E}_{2}$ increased NMDA receptor-mediated EPSPs (Foy et al., 1999). Differences in the sex of the animals and the concentrations of $\mathrm{E}_{2}$ used likely account for these different results.

In all, the present study demonstrates that $\mathrm{E}_{2}$ exerts a facilitating effect on CA3-CA1 excitatory synaptic transmission in both a chronic and an acute manner, and that both effects depend on the circulating $\mathrm{E}_{2}$ level. It is noteworthy that chronic (Rudick and Woolley, 2001) and acute $\mathrm{E}_{2}$ exposures (Huang and Woolley, 2012) also reduce inhibitory synaptic transmission onto CA1 pyramidal neurons-another mechanism that increases the net excitatory drive onto these hippocampal output neurons. We previously reported that long-term ovarian hormone loss reduces the intrinsic excitability (IE; or propensity to generate AP in response to input signals) of CA1 pyramidal neurons and abolishes $\mathrm{E}_{2}$ 's acute increase of IE-changes in membrane properties that also cannot be reversed by delayed $\mathrm{E}_{2}$ treatment (Wu et al., 2011). Thus, long-term ovarian hormone loss in young adult female rats impairs hippocampal function by reducing both information transfer between CA3 and CA1 pyramidal neurons and information throughput by CA1 pyramidal neurons to downstream cortical targets. Our research highlights the importance of $E_{2}$ in maintaining and regulating neural circuit properties relevant for cognition.

\section{References}

Arai AC, Xia YF, Kessler M, Phillips D, Chamberlin R, Granger R, Lynch G (2002) Effects of 5'-alkyl-benzothiadiazides on (R,S)-alpha-amino-3hydroxy-5-methyl-4-isoxazolepropionic acid (AMPA) receptor biophysics and synaptic responses. Mol Pharmacol 62:566-577. CrossRef Medline

Barnes CA, Rao G, Foster TC, McNaughton BL (1992) Region-specific age effects on AMPA sensitivity: electrophysiological evidence for loss of synaptic contacts in hippocampal field CA1. Hippocampus 2:457-468. CrossRef Medline

Barria A, Muller D, Derkach V, Griffith LC, Soderling TR (1997) Regulatory phosphorylation of AMPA-type glutamate receptors by CaM-KII during long-term potentiation. Science 276:2042-2045. CrossRef Medline

Bi R, Broutman G, Foy MR, Thompson RF, Baudry M (2000) The tyrosine kinase and mitogen-activated protein kinase pathways mediate multiple effects of estrogen in hippocampus. Proc Natl Acad Sci U S A 97:36023607. CrossRef Medline

Bloodgood BL, Sabatini BL (2007) Nonlinear regulation of unitary synaptic signals by $\mathrm{CaV}(2.3)$ voltage-sensitive calcium channels located in dendritic spines. Neuron 53:249-260. CrossRef Medline

Brake WG, Alves SE, Dunlop JC, Lee SJ, Bulloch K, Allen PB, Greengard P, McEwen BS (2001) Novel target sites for estrogen action in the dorsal hippocampus: an examination of synaptic proteins. Endocrinology 142: 1284-1289. CrossRef Medline

Bridges RS, Byrnes EM (2006) Reproductive experience reduces circulating 17beta-estradiol and prolactin levels during proestrus and alters estrogen sensitivity in female rats. Endocrinology 147:2575-2582. CrossRef Medline

Buckle PJ, Haas HL (1982) Enhancement of synaptic transmission by 4-aminopyridine in hippocampal slices of the rat. J Physiol 326:109-122. Medline

Carroll RC, Nicoll RA, Malenka RC (1998) Effects of PKA and PKC on miniature excitatory postsynaptic currents in CAl pyramidal cells. J Neurophysiol 80:2797-2800. Medline

Daniel JM, Fader AJ, Spencer AL, Dohanich GP (1997) Estrogen enhances performance of female rats during acquisition of a radial arm maze. Horm Behav 32:217-225. CrossRef Medline

Daniel JM, Hulst JL, Berbling JL (2006) Estradiol replacement enhances working memory in middle-aged rats when initiated immediately after ovariectomy but not after a long-term period of ovarian hormone deprivation. Endocrinology 147:607-614. Medline

Dobrunz LE, Stevens CF (1997) Heterogeneity of release probability, facilitation, and depletion at central synapses. Neuron 18:995-1008. CrossRef Medline

Fader AJ, Hendricson AW, Dohanich GP (1998) Estrogen improves performance of reinforced T-maze alternation and prevents the amnestic effects of scopolamine administered systemically or intrahippocampally. Neurobiol Learn Mem 69:225-240. CrossRef Medline

Farrag AK, Khedr EM, Abdel-Aleem H, Rageh TA (2002) Effect of surgical menopause on cognitive functions. Dement Geriatr Cogn Disord 13:193198. CrossRef Medline

Foy MR, Chiaia NL, Teyler TJ (1984) Reversal of hippocampal sexual dimorphism by gonadal steroid manipulation. Brain Res 321:311-314. CrossRef Medline

Foy MR, Xu J, Xie X, Brinton RD, Thompson RF, Berger TW (1999) 17betaestradiol enhances NMDA receptor-mediated EPSPs and long-term potentiation. J Neurophysiol 81:925-929. Medline

Frye CA, Duffy CK, Walf AA (2007) Estrogens and progestins enhance spatial learning of intact and ovariectomized rats in the object placement task. Neurobiol Learn Mem 88:208-216. CrossRef Medline

Fugger HN, Kumar A, Lubahn DB, Korach KS, Foster TC (2001) Examination of estradiol effects on the rapid estradiol mediated increase in hippocampal synaptic transmission in estrogen receptor alpha knockout mice. Neurosci Lett 309:207-209. CrossRef Medline

Gallagher M, Pelleymounter MA (1988) Spatial learning deficits in old rats: a model for memory decline in the aged. Neurobiol Aging 9:549-556. CrossRef Medline

George MS, Abbott LF, Siegelbaum SA (2009) HCN hyperpolarizationactivated cation channels inhibit EPSPs by interactions with M-type $\mathrm{K}(+)$ channels. Nat Neurosci 12:577-584. CrossRef Medline

Gibbs RB (2000) Long-term treatment with estrogen and progesterone enhances acquisition of a spatial memory task by ovariectomized aged rats. Neurobiol Aging 21:107-116. CrossRef Medline

Gillessen T, Alzheimer C (1997) Amplification of EPSPs by low Ni(2+)and amiloride-sensitive $\mathrm{Ca} 2+$ channels in apical dendrites of rat $\mathrm{CA} 1$ pyramidal neurons. J Neurophysiol 77:1639-1643. Medline

Gould E, Woolley CS, Frankfurt M, McEwen BS (1990) Gonadal steroids regulate dendritic spine density in hippocampal pyramidal cells in adulthood. J Neurosci 10:1286-1291. Medline

Gruart A, Muñoz MD, Delgado-García JM (2006) Involvement of the CA3CA1 synapse in the acquisition of associative learning in behaving mice. J Neurosci 26:1077-1087. CrossRef Medline

Hampson RE, Rogers G, Lynch G, Deadwyler SA (1998) Facilitative effects of the ampakine CX516 on short-term memory in rats: enhancement of delayed-nonmatch-to-sample performance. J Neurosci 18:2740-2747. Medline

Hell JW, Westenbroek RE, Warner C, Ahlijanian MK, Prystay W, Gilbert MM, Snutch TP, Catterall WA (1993) Identification and differential subcellular localization of the neuronal class $C$ and class D L-type calcium channel alpha 1 subunits. J Cell Biol 123:949-962. CrossRef Medline

Hjelmstad GO, Nicoll RA, Malenka RC (1997) Synaptic refractory period provides a measure of probability of release in the hippocampus. Neuron 19:1309-1318. CrossRef Medline

Huang GZ, Woolley CS (2012) Estradiol acutely suppresses inhibition in the hippocampus through a sex-specific endocannabinoid and mGluRdependent mechanism. Neuron 74:801-808. CrossRef Medline

Inagaki T, Kaneko N, Zukin RS, Castillo PE, Etgen AM (2012) Estradiol attenuates ischemia-induced death of hippocampal neurons and en- 
hances synaptic transmission in aged, long-term hormone-deprived female rats. PLoS One 7:e38018. CrossRef Medline

Johnston D, Hoffman DA, Magee JC, Poolos NP, Watanabe S, Colbert CM, Migliore M (2000) Dendritic potassium channels in hippocampal pyramidal neurons. J Physiol 525:75-81. CrossRef Medline

Kadar T, Silbermann M, Brandeis R, Levy A (1990) Age-related structural changes in the rat hippocampus: correlation with working memory deficiency. Brain Res 512:113-120. CrossRef Medline

Kalra SP, Kalra PS (1974) Effects of circulating estradiol during rat estrous cycle on LH release following electrochemical stimulation of preoptic brain or administration of synthetic LRF. Endocrinology 94:845-851. CrossRef Medline

Knafo S, Venero C, Sánchez-Puelles C, Pereda-Peréz I, Franco A, Sandi C, Suárez LM, Solís JM, Alonso-Nanclares L, Martín ED, Merino-Serrais P, Borcel E, Li S, Chen Y, Gonzalez-Soriano J, Berezin V, Bock E, Defelipe J, Esteban JA (2012) Facilitation of AMPA receptor synaptic delivery as a molecular mechanism for cognitive enhancement. PLoS Biol 10: e1001262. CrossRef Medline

Korn H, Triller A, Mallet A, Faber DS (1981) Fluctuating responses at a central synapse: $\mathrm{n}$ of binomial fit predicts number of stained presynaptic boutons. Science 213:898-901. CrossRef Medline

Korol DL, Kolo LL (2002) Estrogen-induced changes in place and response learning in young adult female rats. Behav Neurosci 116:411-420. CrossRef Medline

Korol DL, Malin EL, Borden KA, Busby RA, Couper-Leo J (2004) Shifts in preferred learning strategy across the estrous cycle in female rats. Horm Behav 45:330-338. CrossRef Medline

Kovalchuk Y, Eilers J, Lisman J, Konnerth A (2000) NMDA receptormediated subthreshold $\mathrm{Ca}(2+)$ signals in spines of hippocampal neurons. J Neurosci 20:1791-1799. Medline

Kramár EA, Chen LY, Brandon NJ, Rex CS, Liu F, Gall CM, Lynch G (2009) Cytoskeletal changes underlie estrogen's acute effects on synaptic transmission and plasticity. J Neurosci 29:12982-12993. CrossRef Medline

Leuner B, Mendolia-Loffredo S, Shors TJ (2004) High levels of estrogen enhance associative memory formation in ovariectomized females. Psychoneuroendocrinology 29:883-890. CrossRef Medline

Lipowsky R, Gillessen T, Alzheimer C (1996) Dendritic Na + channels amplify EPSPs in hippocampal CA1 pyramidal cells. J Neurophysiol 76: 2181-2191. Medline

Liu F, Day M, Muñiz LC, Bitran D, Arias R, Revilla-Sanchez R, Grauer S, Zhang G, Kelley C, Pulito V, Sung A, Mervis RF, Navarra R, Hirst WD, Reinhart PH, Marquis KL, Moss SJ, Pangalos MN, Brandon NJ (2008) Activation of estrogen receptor-beta regulates hippocampal synaptic plasticity and improves memory. Nat Neurosci 11:334-343. CrossRef Medline

Luine VN, Jacome LF, Maclusky NJ (2003) Rapid enhancement of visual and place memory by estrogens in rats. Endocrinology 144:2836-2844. CrossRef Medline

Malinow R, Tsien RW (1990) Presynaptic enhancement shown by wholecell recordings of long-term potentiation in hippocampal slices. Nature 346:177-180. CrossRef Medline

Manabe T, Wyllie DJ, Perkel DJ, Nicoll RA (1993) Modulation of synaptic transmission and long-term potentiation: effects on paired pulse facilitation and EPSC variance in the CA1 region of the hippocampus. J Neurophysiol 70:1451-1459. Medline

Marino M, Galluzzo P, Ascenzi P (2006) Estrogen signaling multiple pathways to impact gene transcription. Curr Genomics 7:497-508. CrossRef Medline

Markowska AL, Savonenko AV (2002) Effectiveness of estrogen replacement in restoration of cognitive function after long-term estrogen withdrawal in aging rats. J Neurosci 22:10985-10995. Medline

Milner TA, McEwen BS, Hayashi S, Li CJ, Reagan LP, Alves SE (2001) Ultrastructural evidence that hippocampal alpha estrogen receptors are located at extranuclear sites. J Comp Neurol 429:355-371. CrossRef Medline

Milner TA, Ayoola K, Drake CT, Herrick SP, Tabori NE, McEwen BS, Warrier S, Alves SE (2005) Ultrastructural localization of estrogen receptor beta immunoreactivity in the rat hippocampal formation. J Comp Neurol 491:81-95. CrossRef Medline

Monaghan MM, Trimmer JS, Rhodes KJ (2001) Experimental localization of Kv1 family voltage-gated $\mathrm{K}+$ channel alpha and beta subunits in rat hippocampal formation. J Neurosci 21:5973-5983. Medline
Murthy VN, Sejnowski TJ, Stevens CF (1997) Heterogeneous release properties of visualized individual hippocampal synapses. Neuron 18:599_ 612. CrossRef Medline

Nakamura K, Hioki H, Fujiyama F, Kaneko T (2005) Postnatal changes of vesicular glutamate transporter (VGluT) 1 and VGluT2 immunoreactivities and their colocalization in the mouse forebrain. J Comp Neurol 492: 263-288. CrossRef Medline

Nappi RE, Sinforiani E, Mauri M, Bono G, Polatti F, Nappi G (1999) Memory functioning at menopause: impact of age in ovariectomized women. Gynecol Obstet Invest 47:29-36. CrossRef Medline

Ngo-Anh TJ, Bloodgood BL, Lin M, Sabatini BL, Maylie J, Adelman JP (2005) SK channels and NMDA receptors form a Ca2+-mediated feedback loop in dendritic spines. Nat Neurosci 8:642-649. CrossRef Medline

Parajuli LK, Nakajima C, Kulik A, Matsui K, Schneider T, Shigemoto R, Fukazawa Y (2012) Quantitative regional and ultrastructural localization of the $\mathrm{Ca}(\mathrm{v}) 2.3$ subunit of R-type calcium channel in mouse brain. J Neurosci 32:13555-13567. CrossRef Medline

Pastalkova E, Serrano P, Pinkhasova D, Wallace E, Fenton AA, Sacktor TC (2006) Storage of spatial information by the maintenance mechanism of LTP. Science 313:1141-1144. CrossRef Medline

Phillips SM, Sherwin BB (1992) Effects of estrogen on memory function in surgically menopausal women. Psychoneuroendocrinology 17:485-495. CrossRef Medline

Poleg-Polsky A, Diamond JS (2011) Imperfect space clamp permits electrotonic interactions between inhibitory and excitatory synaptic conductances, distorting voltage clamp recordings. PLoS One 6:e19463. CrossRef Medline

Puoliväli J, Wang J, Heikkinen T, Heikkilä M, Tapiola T, van Groen T, Tanila H (2002) Hippocampal A beta 42 levels correlate with spatial memory deficit in APP and PS1 double transgenic mice. Neurobiol Dis 9:339-347. CrossRef Medline

Ricoy UM, Mao P, Manczak M, Reddy PH, Frerking ME (2011) A transgenic mouse model for Alzheimer's disease has impaired synaptic gain but normal synaptic dynamics. Neurosci Lett 500:212-215. CrossRef Medline

Rocca WA, Bower JH, Maraganore DM, Ahlskog JE, Grossardt BR, de Andrade M, Melton LJ 3rd (2007) Increased risk of cognitive impairment or dementia in women who underwent oophorectomy before menopause. Neurology 69:1074-1083. CrossRef Medline

Rudick CN, Woolley CS (2001) Estrogen regulates functional inhibition of hippocampal CA1 pyramidal cells in the adult female rat. J Neurosci 21:6532-6543. Medline

Sharrow KM, Kumar A, Foster TC (2002) Calcineurin as a potential contributor in estradiol regulation of hippocampal synaptic function. Neuroscience 113:89-97. CrossRef Medline

Sherwin BB (1988) Estrogen and/or androgen replacement therapy and cognitive functioning in surgically menopausal women. Psychoneuroendocrinology 13:345-357. CrossRef Medline

Shi SH, Hayashi Y, Petralia RS, Zaman SH, Wenthold RJ, Svoboda K, Malinow R (1999) Rapid spine delivery and redistribution of AMPA receptors after synaptic NMDA receptor activation. Science 284:1811-1816. CrossRef Medline

Smejkalova T, Woolley CS (2010) Estradiol acutely potentiates hippocampal excitatory synaptic transmission through a presynaptic mechanism. J Neurosci 30:16137-16148. CrossRef Medline

Smith MS, Freeman ME, Neill JD (1975) The control of progesterone secretion during the estrous cycle and early pseudopregnancy in the rat: prolactin, gonadotropin and steroid levels associated with rescue of the corpus luteum of pseudopregnancy. Endocrinology 96:219-226. CrossRef Medline

Stuart G, Sakmann B (1995) Amplification of EPSPs by axosomatic sodium channels in neocortical pyramidal neurons. Neuron 15:1065-1076. CrossRef Medline

Tang YP, Shimizu E, Dube GR, Rampon C, Kerchner GA, Zhuo M, Liu G, Tsien JZ (1999) Genetic enhancement of learning and memory in mice. Nature 401:63-69. CrossRef Medline

Teyler TJ, Vardaris RM, Lewis D, Rawitch AB (1980) Gonadal steroids: effects on excitability of hippocampal pyramidal cells. Science 209:10171018. CrossRef Medline

Tippens AL, Pare JF, Langwieser N, Moosmang S, Milner TA, Smith Y, Lee A (2008) Ultrastructural evidence for pre- and postsynaptic localization of Cav1.2 L-type Ca2+ channels in the rat hippocampus. J Comp Neurol 506:569-583. CrossRef Medline 
Turner DA, Chen Y, Isaac JT, West M, Wheal HV (1997) Excitatory synaptic site heterogeneity during paired pulse plasticity in CA1 pyramidal cells in rat hippocampus in vitro. J Physiol 500:441-461. Medline

Waters EM, Mitterling K, Spencer JL, Mazid S, McEwen BS, Milner TA (2009) Estrogen receptor alpha and beta specific agonists regulate expression of synaptic proteins in rat hippocampus. Brain Res 1290:1-11. CrossRef Medline

Whiteman MK, Hillis SD, Jamieson DJ, Morrow B, Podgornik MN, Brett KM, Marchbanks PA (2008) Inpatient hysterectomy surveillance in the United States, 2000-2004. Am J Obstet Gynecol 198:34.e1-34.e7. Medline

Whitlock JR, Heynen AJ, Shuler MG, Bear MF (2006) Learning induces long-term potentiation in the hippocampus. Science 313:1093-1097. CrossRef Medline

Williams SR, Mitchell SJ (2008) Direct measurement of somatic voltage clamp errors in central neurons. Nat Neurosci 11:790-798. CrossRef Medline

Wilson NR, Kang J, Hueske EV, Leung T, Varoqui H, Murnick JG, Erickson JD, Liu G (2005) Presynaptic regulation of quantal size by the vesicular glutamate transporter VGLUT1. J Neurosci 25:6221-6234. CrossRef Medline

Wong M, Moss RL (1992) Long-term and short-term electrophysiological effects of estrogen on the synaptic properties of hippocampal CA1 neurons. J Neurosci 12:3217-3225. Medline
Woolley CS, McEwen BS (1993) Roles of estradiol and progesterone in regulation of hippocampal dendritic spine density during the estrous cycle in the rat. J Comp Neurol 336:293-306. CrossRef Medline

Woolley CS, Wenzel HJ, Schwartzkroin PA (1996) Estradiol increases the frequency of multiple synapse boutons in the hippocampal CA1 region of the adult female rat. J Comp Neurol 373:108-117. CrossRef Medline

Woolley CS, Weiland NG, McEwen BS, Schwartzkroin PA (1997) Estradiol increases the sensitivity of hippocampal CA1 pyramidal cells to NMDA receptor-mediated synaptic input: correlation with dendritic spine density. J Neurosci 17:1848-1859. Medline

Wu WW, Adelman JP, Maylie J (2011) Ovarian hormone deficiency reduces intrinsic excitability and abolishes acute estrogen sensitivity in hippocampal CA1 pyramidal neurons. J Neurosci 31:2638-2648. CrossRef Medline

Wyllie DJ, Nicoll RA (1994) A role for protein kinases and phosphatases in the $\mathrm{Ca}(2+)$-induced enhancement of hippocampal AMPA receptormediated synaptic responses. Neuron 13:635-643. CrossRef Medline

Wyllie DJ, Manabe T, Nicoll RA (1994) A rise in postsynaptic Ca2+ potentiates miniature excitatory postsynaptic currents and AMPA responses in hippocampal neurons. Neuron 12:127-138. CrossRef Medline

Yuste R, Majewska A, Cash SS, Denk W (1999) Mechanisms of calcium influx into hippocampal spines: heterogeneity among spines, coincidence detection by NMDA receptors, and optical quantal analysis. J Neurosci 19:1976-1987. Medline 